\title{
Restoring earth surface processes through landform design. A 13-year monitoring of a geomorphic reclamation model for quarries on slopes
}

\author{
J.F. Martín-Duque, ${ }^{1} *$ M.A. Sanz, ${ }^{1}$ J.M. Bodoque, ${ }^{2}$ A. Lucía ${ }^{1}$ and C. Martín-Moreno ${ }^{1}$

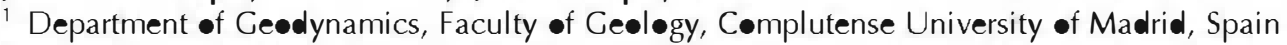

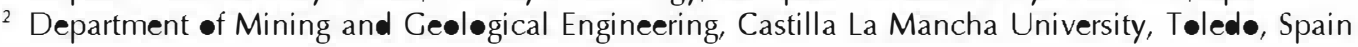

ABSTRACT: The application of geømerphic principles tø land reclamatiøn after surface mining has been reperted in the literature

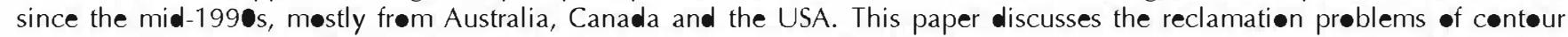

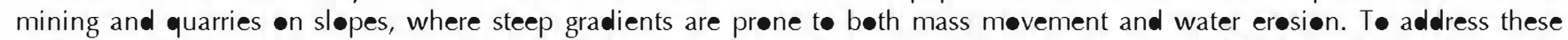
problems simultaneously, a geomerphic model for reclaiming surface mined slopes is described. Called the 'highwall-trench-

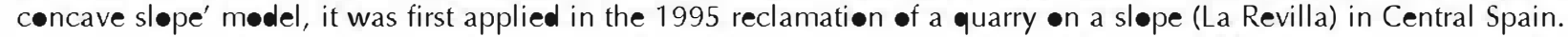

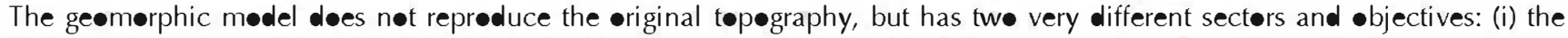

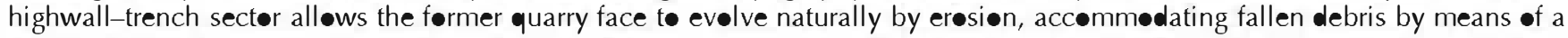

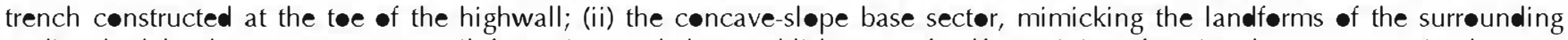
undisturbed landscape, prometes søil formation and the establishment of self-sustaining, functional ecosystems in the area

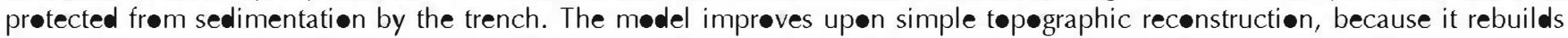

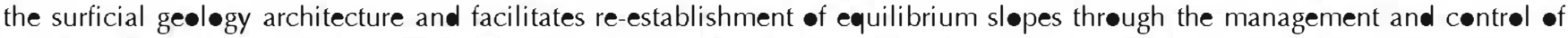
geomerphic precesses.

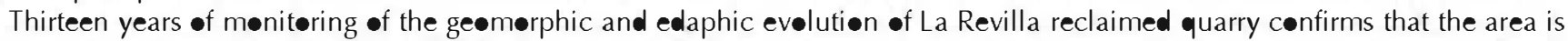
functioning as intended: the highwall is backwasting and material is accumulating at the trench, permitting the recevery $\bullet$ søils

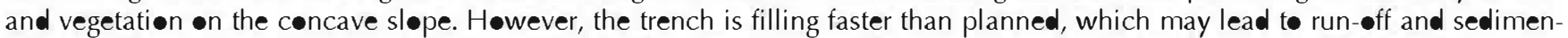

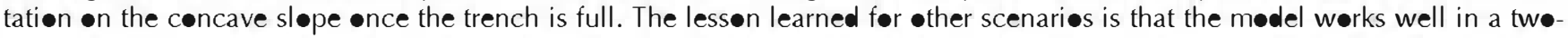
dimensional scheme, but requires a three-dimensional drainage management, breaking the reclaimed area inte several watersheds with stream channels.

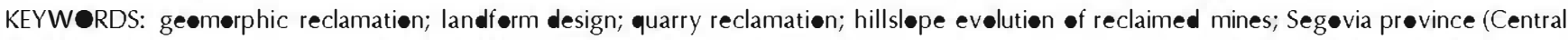
Spain)

\section{Introduction}

This paper discusses a geømerphic mødel før the reclamatiøn -f an abandened silica sand quarry $\bullet$ a sløpe of Central Spain (La Revilla), and decuments its 13-year geomerphic and edaphic maturation. Reclamation was planned and executed using geømerphic principles, and it invelved lecal landform-

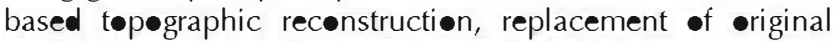

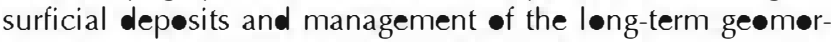
phic dynamics. The løgic behind this study requires an understanding of the role of geomerphic processes in mining reclamation with attention to specific rehabilitation problems of quarries $\bullet$ sløpes, sø this backgrøund is presented before discussing the study in detail.
Mining moves earth and shapes new landscapes

Cumulative effects of human-induced earth mevements have

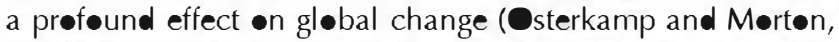
1996): 'humans are arguably the most impertant geomerphic agent currently shaping the surface of Earth' (Høoke, 1994, p. 217; Høoke, 1999). In particular, surface mining is most efficient at moving earth (Høoke, 1994).

Surface mining impeses severe ecoløgical effects •n the land because alteration affects vegetation, søils, bedrøck and landforms. Surface hydrølogy and grøundwater levels and flow paths are alsø changed (Osterkamp and Jeseph, 2000; Nicelau and Asensie, 2000). 


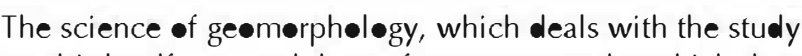
-f earth's landforms and the surface precesses by which they are shaped (Gødfrey and Cleaves, 1991), prevides a useful framewerk both for an understanding of the envirømental effects of surface mining, including changes in erosionsedimentation prøcesses and søil prøperties (Wilkinsøn and McElrøy, 2007), and for designing the most apprøpriate strategies for reclamation (Tøy and Hadley, 1987).

Surface mining reclamation allows the design and complete reconstruction of new landforms. This is different, for instance, frøm the rehabilitation of røadcuts and earthfills in highway cønstruction, or høusing develøpments, where there is a limited possibility for geomerphic design (Nic lau, 2003). Landform recenstruction is the majer phase of the mining reclamation process; and earth mevement is the most expensive part of reclamation (Brenner, 1985; Zipper et al., 1989; Envirønment Australia, 1998). Finding the appropriate landform design in mining reclamation can be

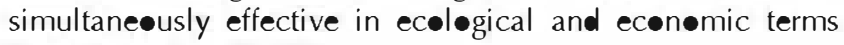
(Sawatsky et al., 1998).

\section{Geomorphic reclamation in surface mining}

The landforms that traditionally result frøm reclaimed mining cuts and spøil banks nearly always have a geømetric tøp graphy - constant-gradient sløpes with benches (graded banks, terraced appearance). They are usually combined with elements to redirect and slow runøff, such as rip-rap, erøsin cøntrol blankets, røck-filled gabiøns, drainpipes, cøncrete

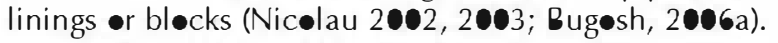

The reasøns argued før these designs are: (i) their geøtechnical stability, which helps prevent mass movement (landslides, failures of tailings dams, etc.); (ii) the run॰ff management frøm the sløpes; and (iii) their ease of construction using existing machinery. The geømetric tøp graphy of mined landscapes is -ften regulated by specific technical instructions of mining safety, as is the case in Spain.

However, 'very few linear slopes with benches are $\bullet$ bserved in nature' (Hancock et al., 2003, p. 1097). Reclamation landførms built using cønventional methøds 'depart cønsiderably frøm the stable natural landforms surrounding them, bøth in perfermance and appearance' (Bugesh, 2006a, p. 156). N•r are these recønstructiøns always successful: with $\bullet$ ut $\bullet \bullet$-ging maintenance, many graded banks fail under water eresion -ver the løng term (L•ch, 1997). Further, the most convenient geometry for controlling mass mevement is nøt usually the -ptimum geømetry for minimizing eresion (McPhail and Rusbridge, 2006). According to Sawatsky et al. (2000), the traditiønal appreach of uniførm sløpes and terracing in mining reclamation results in an immature tøpgraphy not present in

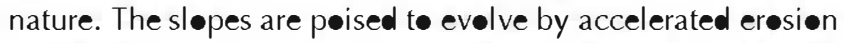
and the terraces can increase erosion during extreme events when their storage capacity is exceeded. Therefore, more than appearance, the main shørtcoming of conventional designs in mining reclamation is that they give little consideration for prøper hydrøløgic function før balanced cønveyance of water and sediment from the land surface' (Bugesh, 2004, p. 241). This often results in high maintenance and liability costs. Anticipation of these costs in a mine permit review can halt a

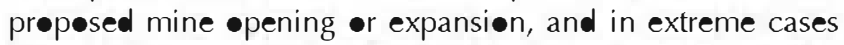
actual failures can halt active mining (Bugesh, 2004, 2009).

Many researchers have reperted the hydrølogic instability -f rectilinear and terraced slopes on mine spoil dumps. Haigh piøneered the study of water erøsion processes and sløpe evolution of surface mine dumps, shøwing the accelerated erøsion of rectilinear slope segments (Haigh, 1979), leading t• gully development (Haigh, 1980). Cøodman and Haigh (1981), studying sløpe evelution on abandened spøil banks of different ages in Eastern Oklahøma, found a marked tendency for the reduction of sløpe crests, the burial of the tøe sløpes, and the extension of the upper convexity and lower concavity at the expense of the rectilinear main slope of the eriginal mine dump. Haigh (1985) summarized this general tendency - sløpe ev lution for initially rectilinear slope prøfiles of mine spoil mounds: they evolve towards a much more stable sigmoid shape.

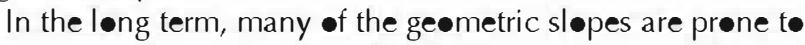
severe eresion, and ence this failure has eccurred, they channel water in concentrated flow paths, leading to severe gullying (Hanceck et al., 2003; Sanz et al., 2008). Sawatsky and Tuttle (1996) suggested that gully eresion can be used as an indicator of the performance and sustainability of mining reclamation. This is because eresion on mined landforms seeks to re-establish the dynamic equilibrium between landforms and processes. Proper landform design in mining reclamation can accomplish part of this work, leaving the 'fine-tuning' to natural processes (Schumm and Rea, 1995; Toy and Black, 2000; Toy and Chuse, 2005). Therefore, the design of reclaimed landførms int the shape that geomerphic prøcesses wøuld tend to erøle them under existing envirønmental conditions should be the aim of any surface mining reclamation (Bugesh, 2004, 2007).

As variøus countries started to enferce the protection of aquatic ecosystems located downstream frøm disturbed (mined) areas (e.g. the US Clean Water Act of 1972), investigat॰rs, practitiøners and regulaters began to shøw much mere interest in the eff-site envirømental impacts of run॰ff and erøsion frøm mined lands and to place mere emphasis on løng-term stability. Unstable landforms prevent the develop-

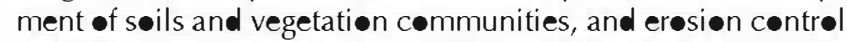
is difficult and uneconømical (Riley, 1995; Tøy and Black,

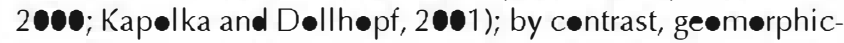
based sustainable landscapes are expected to generate efficient engineering sølutiøns that generally decrease ec $\bullet \bullet$ gical impacts (Bender et al., 2000). Compatibility between envirønmental pretection and mine profitability can be achieved through integrated minewater management (Sawatsky et al.,

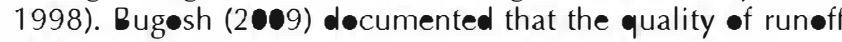
water frøm mined lands reclaimed using fluvial geøm»rphic criteria can be equal to $\bullet$ better than that of contigu natural lands. In arid and semiarid areas, however, eresion

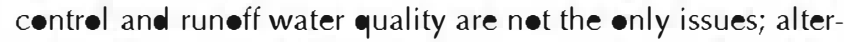
native appreaches that mimic the geomerphic function of the natural landscape can 'harvest' water, providing a key facter in the restoration of ecosystems in water-scarce envirenments (Bugesh, 2004).

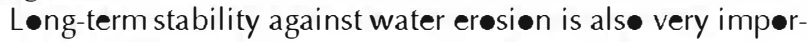
tant in sensitive envirønments, such as the aquatic ecosystems - Upper Tagus region of Spain (Sanz et al., 2008) •r when dealing with tailings containing løng-lived radiønuclides, where structures need to be stable for at least 1000 years (Willgeøse and Riley, 1998).

In this framework, where geometric designs deminate, many authørs have argued in fav ur of geømerphic apprøaches: 'nature can prøvide anal gues for pøst-mining landscapes in terms of landscape stability and als in terms of the rehabilitated structure blending in with the surrounding undisturbed landscape' (Hancock et al., 2003, p. 1097); designing sløpes and landforms based on natural ones can achieve the dual gøal of being mere visually attractive and being mere functiønal and cost effective (Schør and Gray, 2007); landførm design in mining reclamation should make the final landform

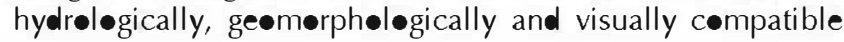




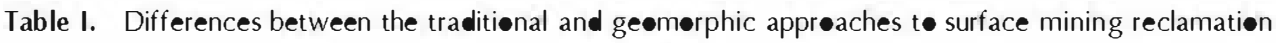

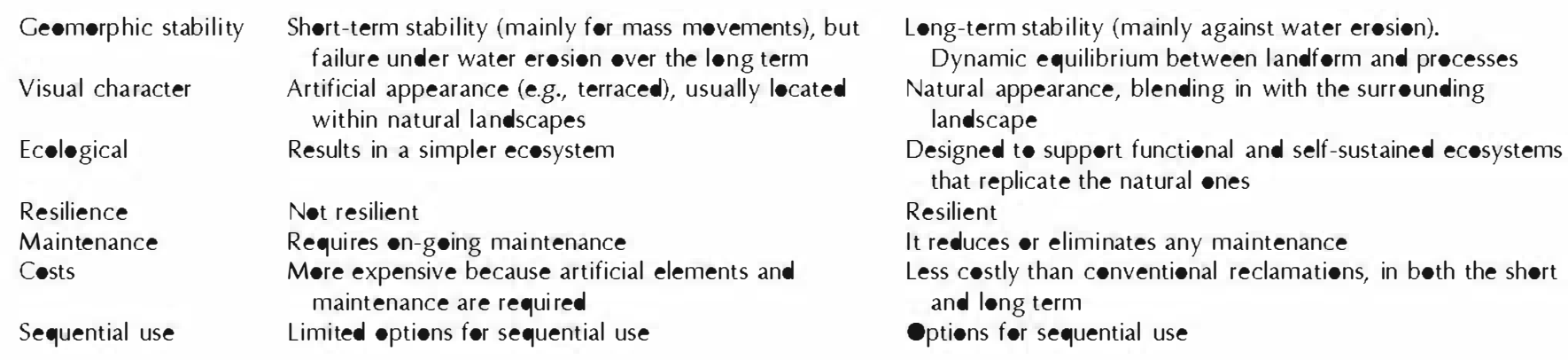

with the surrounding area and remain stable for the long term (Hancock et al., 2003); the design of mature landforms 'serves to improve the aesthetic appearance, prøvide a wider range - f habitats for wildlife and avoid the large surface-flow rates typical of løng, straight slopes' (Sawatsky et al., 2000, p. 28). Sustainable reclaimed mined landscapes $\bullet$ ver the long term can be achieved through attention to geomerphic parameters (Table I) (Riley, 1995; Keys et al., 1995).

The use of gemerphic principles in surface mining reclamation is well established in Canada, Australia and the United States. In Canada, Sawatsky and Beckstead (1996) and Sawatsky et al. $(1996,1998)$ call for the application of geemorphic principles in the design of mined land reclamation før integrated minewater management. Cøntributiøns frøm

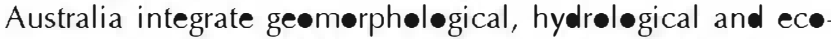
l-gical principles in the reclamation of areas affected by surface mining, often using SIBERIA landscape ev lution søt-

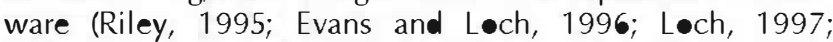
Envirønment Australia, 1998; Willgeose and Riley, 1998; Evans and Willgeose, 2000; Evans et al., 2000; Hanceck et al., 2003). In the USA, the contributions of Tøy and collaberators are benchmarks in this field (Tøy and Hadley, 1987; T•y and Fester, 1998; Tøy and Black, 2000; Tøy and Griffith, 2001; T•y and Chuse, 2005). Als• •utstanding in the USA is a specific landform design software (Natural Regrade with GeøFluv ${ }^{\top M}$ ), driven by geømerphic principles (Carlsøn Søftware

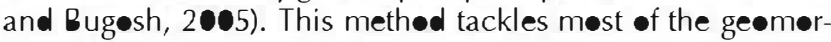
phic arguments because it essentially reproduces the natural landform's evelution to the mature stage, resulting in stable slopes and channels, in balance with the lecal envirenmental conditions (Bugesh, 2004, 2007). The US Office of Surface Mining (OSM) awarded 'National' and 'Best of the Best'

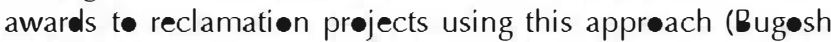
and Eckels, 2006).

The possibilities of applying geomerphic approaches to surface mining reclamation depend on: (i) the nature of the extracted mineral; (ii) the exploitation methed; (iii) the final shape of the mined landscape; and (iv) the lithologies of the new landforms (highwalls, benches, terraces, waste dumps, etc.). Table II characterizes the reclamation geomerphic framework of the mest cømmen types of surface mining.

\section{The specific problems of contour mining and slope quarrying}

Because of their steep sløpes, cøntøur mining and quarrying -n sløpes create specific reclamation difficulties favøuring slope instability and water erosion, allowing sediments to reach stream channels below the mines. Eventually, more distant streams and rivers can be affected.

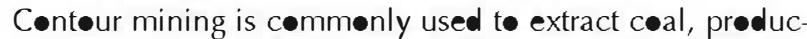
ing large volumes of mine spoil. This type of mining was dramatically altered in 1977 in the USA by enactment of the Surface Mining Cøntrol and Reclamation Act (SMCRA), which required that all mining speil had to be stabilized and returned to the 'approximate eriginal contøur (AOC)' (Brenner, 1985). It meant that the extensive highwall cuts had to be cevered and returned to contour. This act has had an impertant impact -n reclamation in $\bullet$ ther countries.

The AOC requirement led tø søme contrøversial practices. Several authers (Brenner, 1985; Bell et al., 1989; Zipper et al., 1989;) felt that the near-universal use of the AOC requirement

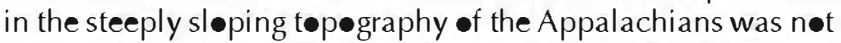

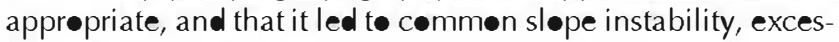
sive mining costs, increased erosion and loss of post-mining land-use value. The main reasen for these failures is that this type of reclamation cannot replicate the original geølogic structure and søil preperties. Haigh (1992) prevides a similar example of mining reclamation failure in Wales.

As the abeve examples illustrate, the emphasis in reclama-

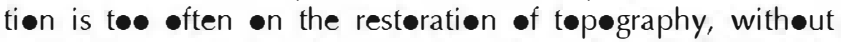
considering the structure and nature of the materials beneath.

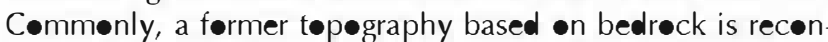
structed with spøils, changing slope stability conditions dramatically. Therefore, a truly geomerphic appreach to surface mining reclamation should always consider that the surficial geøløy may have a majer effect $\bullet$ surficial and subsurficial hydrology, and therefore on the long-term stability of the reclaimed landforms. This consideration may lead tø landform designs different frøm the •riginal cøntøur. This circumstance

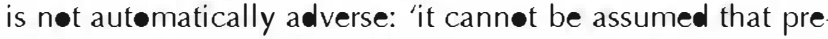
disturbance equilibrium landforms are necessarily pest-recla mation equilibrium landforms' (Tøy and Black, 2000, p. 45). Bugesh (2006b) coined the term 'asterøid effect' to describe the effect of a surface mine on earth materials; the loose backfill compares with the pre-mine consølidated røck as the earth material remaining after an aster id impact cømpares with the pre-impact rock. Consequently, the unconsolidated backfill usually demands a very different landform to achieve stability against eresion. For instance, whereas the pre-mine cønsølidated recks can have different drainage patterns, a dendritic drainage pattern can better suit the reclamation, because it is typical of unconsolidated materials (Bugesh, 2004). Summing up, the SMCRA shows an example in which the $A O C$ requirement resulted in a very uniform mining reclamation. Tø restrictive regulations can discourage the devel-pment of innevative techniques, showing that 'n॰ single reclamation strategy is applicable to all envirenments' (Brenner, 1985, p. 217).

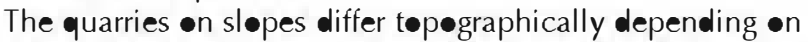
whether or not the material expløited is consølidated. A 


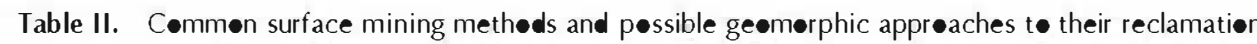

\begin{tabular}{|c|c|c|c|c|c|c|}
\hline \multicolumn{2}{|c|}{ Mining methød } & 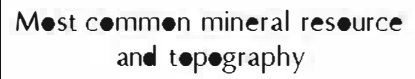 & 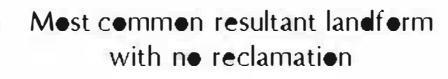 & $\begin{array}{l}\text { Traditienal and mest commen } \\
\text { landf } \bullet \text { rm with reclamatiøn }\end{array}$ & $\begin{array}{l}\text { Main geømørphic reclamatiøn } \\
\text { cønstraints }\end{array}$ & $\begin{array}{l}\text { Geømørphic appreach to reclamation } \\
\text { (theøretical •r actual); literature references }\end{array}$ \\
\hline \multicolumn{2}{|c|}{ Open pit } & 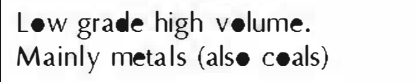 & $\begin{array}{l}\text { Benched circular pit, with } \bullet \text { utside } \\
\text { waste dumps }\end{array}$ & 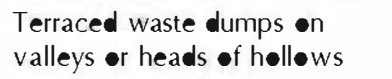 & 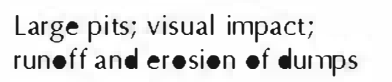 & Dumps designed te replicate lecal landførms \\
\hline \multicolumn{2}{|c|}{ Strip / area } & 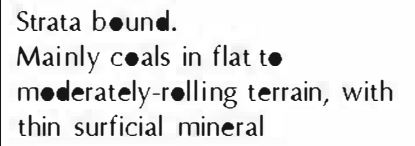 & 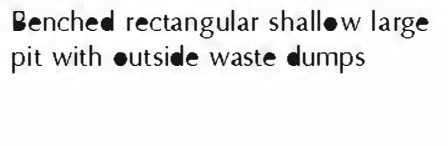 & \multirow{2}{*}{ 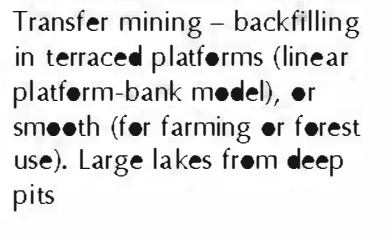 } & \multirow[t]{2}{*}{ Large-scale earth mevements } & \multirow{2}{*}{ 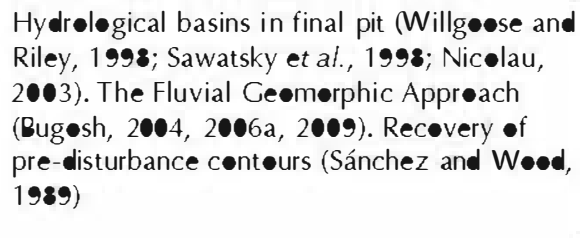 } \\
\hline \multicolumn{2}{|c|}{ Terracing } & $\begin{array}{l}\text { Mainly c•als in flat terrain, } \\
\text { with deep } \bullet \text { thick dep•sits }\end{array}$ & $\begin{array}{l}\text { Benched rectangular deep large pit } \\
\text { with •utside waste dumps }\end{array}$ & & & \\
\hline \multicolumn{2}{|c|}{$\begin{array}{l}\text { Mountaintop } \\
\text { removal }\end{array}$} & $\begin{array}{l}\text { Cøals that underlie the tøp } \bullet \\
\text { møuntain ridges }\end{array}$ & $\begin{array}{l}\text { Benched pit with } \bullet \text { utside waste } \\
\text { dumps }\end{array}$ & 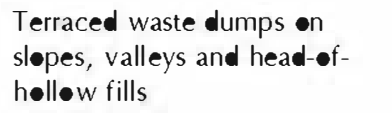 & 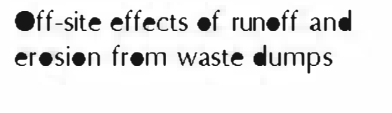 & \multirow{2}{*}{ 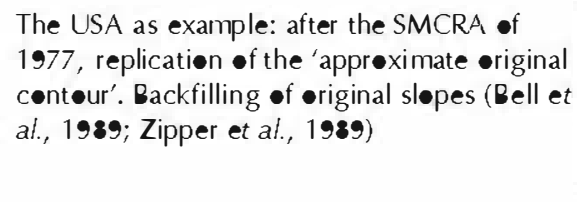 } \\
\hline \multicolumn{2}{|c|}{ Contour } & $\begin{array}{l}\text { Mainly coals mined in hillsides } \\
\text { and steep terrain }\end{array}$ & \multirow{2}{*}{ 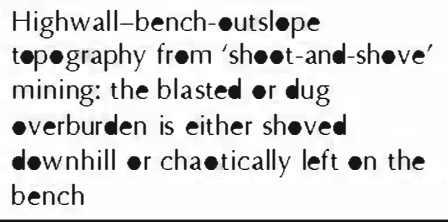 } & \multirow{2}{*}{ 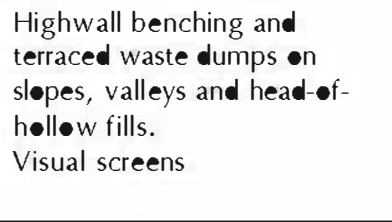 } & \multirow{2}{*}{ 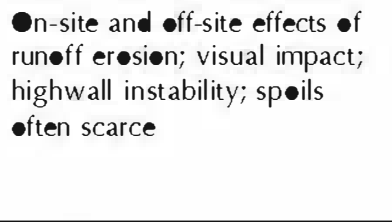 } & \\
\hline \multirow{2}{*}{ 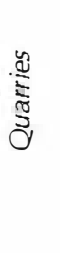 } & Slope & $\begin{array}{l}\text { Mainly industrial and } \\
\text { construction recks and minerals }\end{array}$ & & & & $\begin{array}{l}\text { Highwall-trench- cencave slepe (Martín } \\
\text { Duque et al., 1998) }\end{array}$ \\
\hline & Pit & $\begin{array}{l}\text { Mainly } \bullet \text { rnamental røcks (e.g. } \\
\text { granites) }\end{array}$ & 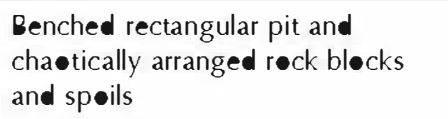 & 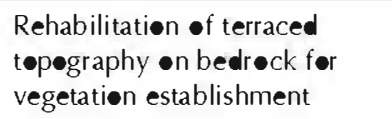 & 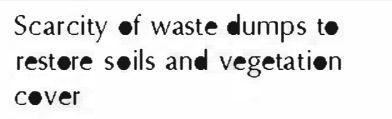 & 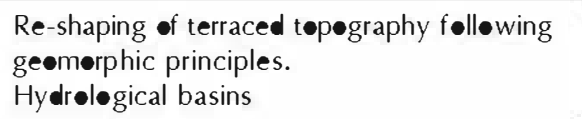 \\
\hline \multicolumn{2}{|c|}{ Gravel pits } & $\begin{array}{l}\text { Aggregates, gravel, and sand in } \\
\text { floodplains and terraces }\end{array}$ & $\begin{array}{l}\text { Rectangular single benched pit. } \\
\text { Often intersects greundwater table }\end{array}$ & $\begin{array}{l}\text { Filling of hølløws and } \\
\text { topsøiling (farming use). } \\
\text { Artificial lakes (natural use) }\end{array}$ & $\begin{array}{l}\text { Scarcity } \bullet \text { waste dumps f } \bullet \\
\text { landf } \bullet r m \text { design. Pit } \bullet \text { ften } \\
\text { beløw water table }\end{array}$ & 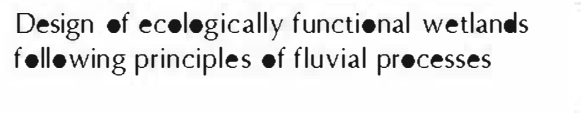 \\
\hline
\end{tabular}


typical quarry on a slope, as the one in Central Spain analysed in this paper, typically consists of: (i) a rrain highwall, vertical or terraced; (ii) a rrain slope shelf or bench (mine plat:orm); and (iii) the waste dumps, usually scarce when most of the rock or mineral is removed. In general, the final cut is large in cornparisen with the spoils For this situation, the reclamation problems (as shown in Table II) are: (i) the highwall stability; (ii) the reclamation of the mine plat orm and any hillside construction within it; (iii) the rranagement of the waste dumps; (iv) the visual impact of the highwall cut; and (v) the potential on-site and off-site effects of runoff and erosion.

This paper describes a 13-year monitoring of a slope gev morphic reclamation model that has dealt with most of these referred reclamation problems at one time - with out returning the eriginal contour, without the highwall elimination, and with the reconstruction of only a sector of the slope. For that, the landform design was inspired by the knowledge of the dynamics of lecal geornerphic precesses.

\section{Case and study area: the reclaimed quarry of La Revilla (Segovia, Spain)}

La Revilla quarry yielded silica sand sediments of Central Spain (Segevia province), of Upper Cretaceous age. In this region, these silica sands are on the slopes of limestone and dolestone-capped mesas and cuestas, but they crop out only in slope gullies because the mesas' silica sand hillslopes are always covered with a carbonate colluvium. On these slopes, rendzic leptosels develop on the consolidated limestones and dolestones of the mesas' and cuestas' rims, and colluvic reg• sols develop on the carbonatic colluvium that drapes the silic a sand (IUSS Working Group WRE, 2007).

The climate is characteristic of the Alediterranean Basin, with a moderate average annual precipitation $(679.1 \mathrm{~mm})$ and temperature $\left(11 \cdot 4^{\circ} \mathrm{C}\right)$. Due to this area's great distance from the sea, its high altitude (1050 m above sea level, m.a.s.l.) and its proximity to the mountain Central System of the lberian Pen insula, the winters are long and cold. Temperatures below $-10^{\circ} \mathrm{C}$ are not uncommon, and snow days average 13 annually. The summers are shert, very dry, and het, with maxirnum daily temperatures frequently close to $40^{\circ} \mathrm{C}$

These climatic conditions and intense human use of the land for more than 1000 years have resuited in characteristic -pen woodlands of holm eak. (Quercus ilex, subsp. sotundifo(1a), white savin juniper (juniperus thurifera), and juniper shrubs (Juniperus commun is subsp. hemisphzerica).

At La Revilla quarry, the silica sand was extracted during the 1970s, a peried in which the Spanish legislative system lacked mining reclamation requirements; the first Spanish mining reclamation act was enacted in 1982. The sand at La Revilla was quarried by directly excavating the slopes. The removed surficial deposits and spoils were either left at the mine's bench or pushed downhill, burying the original søils downslope. The result was a highwall-bench-outslope topography, which left the silica sand and clay spoils exposed, with

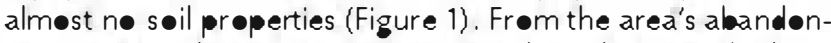
ment to its reclamation, a progressive degradation took place. Within the abandoned mine (on-site), intense erosion and sedimentation eccurred, whereas downslope from the mine (off-site), severe soil degradation and river silting eccurred.

At the beginning of 1994, an opportunity to reclaim this mine was supported through a pregramme of subsidization by the regienal government (Castilla y León), which targeted abandoned mines exploited before 1982. The reclamation project was approved in 1994, and irnplemented in January and February of 1995.

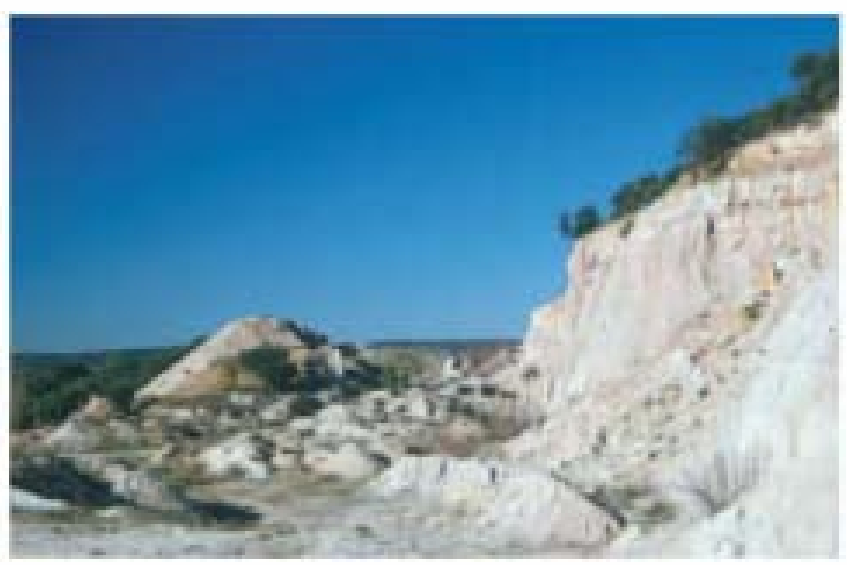

Figure 1. The abandened silica sand quarried slope of $L$ a Revilla, before its geomorphic reclamation:

quamy at the slope of a limest $\bullet$ necapped small mesa, and highwallbench-utslope topography, with a chatic arrangement of scarce sllica sand and clay spoils

For the geomorph ic reclarration model design, the chaotic arrangement of mine dump upon the bench of the abandoned quarry requ ired a new geemerphic reconstruction and a majer classification and movement of earth. The aim of th is geornerphic reclamation was to re-establish a process-landform (Tøy and Hadley, 1987) - in •ther words, to implement the desired precesses by designing and building the appropriate landforms. For that, a highwall-trench--concave slope topegraphic model with twe very different sectors and ebjectives was proposed (Figures 2 and 3):

(1) The highwall-trench secter. The existing quarry highwall would be allowed to degrade in a natural manner, mainly by mass movement. This appreach would accommodate the fallen debris in a trench constructed atthetee of the highwall, so that: (i) they would not everrun the reconstructed concave hillslope toe, where geomerphic stability would permit søil formation; (ii) the accumulation of the fallen debris would imitate, in the long term, the topography and structure of the slopes of the area. In short, at the highwall-trench sector, the geemerphic activity and instability would be allowed to interact

(2) The concave slope sector. On the former quarry fioor, a concave hillslope base was designed to fit the profile of the surrounding undisturbed landscape. The objectives were: (i)

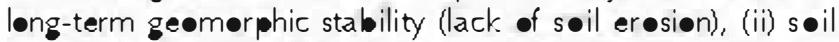
formation, (iii) the establishment of self-sustaining and functional ecosystems. A concave slope was considered the most appropriate, because it replicated the runout gradients of local natural slopes surrounding hillslope bases It was alsø estimated to be the most geornorphologically stable, since as the catchment area increases, slope decreases, reducing the velecity of discharge and its erosive potential (Hancock e ta)., 2003). Actually, this is what natural slope analogues show us: the toe of a natural (erosion-resistant) slope has a lower gradient than the upslope, resulting in a reduced erosion potential.

Excavating a trench in order to disconnect the concave slope from the highwall was a key design feature for the reclarration (see Figure 3), because the decoupling of the two slope segments limited the eversteeping of the concave hillslope toe by slope deposits from the highwall. The geometric model for the optimization of waste durnps in the topegraphical reconstruction is described in detail in Martín-Duque et al. (1998). 


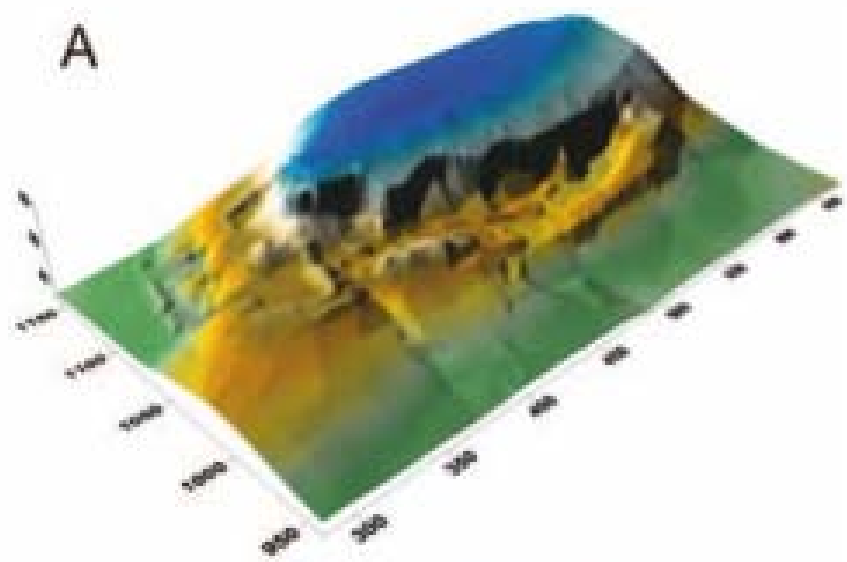

for soil formation at the concave slope, given that: (i) it formed the original substrata of the local hillslope soils on which the mining activity took place; (ii) its loamy texture rade it ideal for edaphic development, allowing a balance between an -ptimum drainage and the accumulation of water and nutrients, raking possible the formation of soil aggregates; and (iii) it had a high calcium content (average of $217.6 \mathrm{mg}$ per $100 \mathrm{~g}$ ), which helps to create the slightly basic $\mathbf{p H}$ optimum for nutrient production for plants and impreves the soil development and structure.

The execution of this geomerphically-guided reclamation took place between January and February of 1995. For an understanding of the 13-year spontaneous evolution of the reclaimed area, it is required to know that the reconstructed concave slope: (i) was sown with a $330 \mathrm{~kg} \mathrm{ha}^{-1}$ mixture of grass and leguminous seed; (ii) was fertilized the first year with a complex fertilizer in a propertion of 12/36/12 (nitrogen/ phosphorus/potassium) at $600 \mathrm{~kg} \mathrm{ha}^{-1}$, to ease the problem of the initial deficiericy of nutrients in the carbonatic colluvium. F•llowing the reclamation work, the area has beer, used sølely for livestock (sheep) grazing with ne further rainterıance. Details beyond these summarized here, and the precise location of the reclaimed quarry, are described in I Aartír-Duque et 2 . (1998).

\section{Methodology}

T• assess whether the reclaimed surface followed the hypothesized evolution, the area was monitored from the spring of 1995 to the spring of 2008 (Table III). This obsersation period is within an appropriate order of magnitude for documenting the beginning of the geomerphic evolution of the highwall (when rnost of it is cut in poorly consolidated sands) and of the edaphic evolution of the reconstructed concave slope.

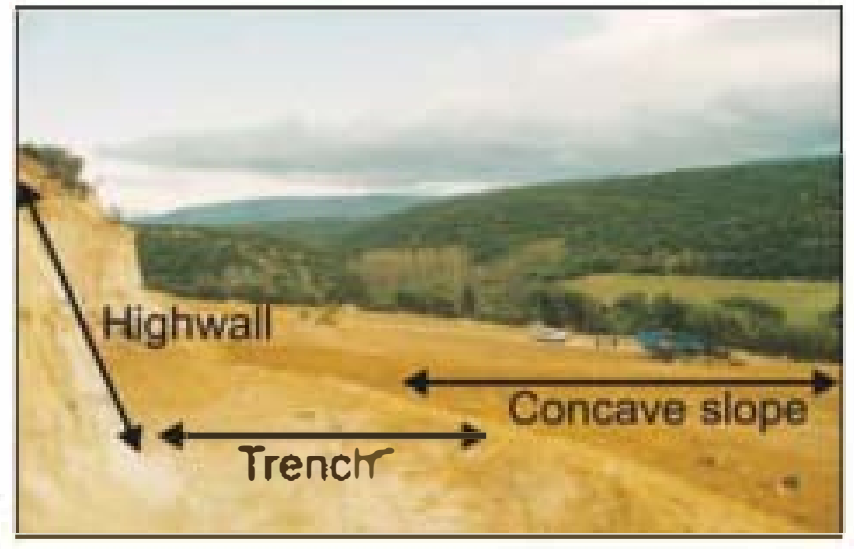

Figure 3. Detail of the highwall-trench $-c$ oncave slope geomerphic model, represented on a phot taken in February 1995, immediately after reclamation was completed.

The landform design included not only a topographical reconstruction, but alse an appropriate arrangement of the substratum and the surficial depesits. The sandy spoil heaps, which had ne edaphic capacities, were planned to be placed as substrata of the concave slope base and covered with the carbonate colluvium. This assemblage of surficial materials replicated the natural protosoil of local slopes.

This carbonate colluvium previously covered the quarried hillslope. It was a surficial deposit derived from the break up and decornposition of the limestone and dolostone rocks that capped and rimmed the exploited silica sands. Our strategy was that carbonatic colluvium was an •ptimum starting point

\section{Topographical survey}

A topographic sursey of the reclaimed area was made with a total station on I Aay 1995. From it, a digital elevation model (DEM) of the former highwall-trerich sector was extracted. Twelve years later, in June 2007 , a high-definition topegraph ic sursey of the same area (the highwall-trench sector) was carried out using newly available terrestrial laser scanner (TLS) technøløgy. Althøugh comparison between both topographical surseys is inhereritly difficult, a contrast of different topegraphical profiles (2D) and of the 3D surfaces of the highwall could be made. The 2D topegraphical profile comparisens offered satisfactory results, but the 3D comparisons were inadequate, due to the precision and different means of -btaining the data in 1995 and in 2007. Therefore, a method for assessing the 3D topegraphical evolution of the highwall-trerich sector was developed. Areas of the highwall that had not suffered either erosion or sedimentation during the rnonitored period were ideritified in the 2007 laser scanner point cloud. These areas remained as small spots, almest vertical sand and limestone cliffs, and were recognized based on the ground phote sursey. With the point cloud of those stable areas of the highwall, a DEM of the former highwall was interpreted. It was done by gerierating 'surfaces of tendency' for those spots that later suffered erosion or sedimeritation. For this analysis, the interpolation methods were based on the analysis of the semivariograms and on kriging interpolaters. Finally, a $3 \mathbf{D}$ comparisen was rade betweer, the 2007 real topography obtained using the TLS - and the 1995 topography - obtained from interpretation of the 2007 surfaces that had not suffered erosion or sedimentation. 
Table III. Mønitoring procedures applied tø the reclaimed quarried slope of La Revilla

\begin{tabular}{|c|c|c|c|c|c|}
\hline \multirow{2}{*}{$\frac{\text { Year }}{\text { (Spring) }}$} & \multicolumn{2}{|c|}{ Highwall-Trench } & \multicolumn{2}{|c|}{ Concave slepe } & \multirow{2}{*}{$\begin{array}{c}\text { Entire } \\
\text { reclaimed area } \\
\text { Oblique aerial } \\
\text { phot suney }\end{array}$} \\
\hline & $\begin{array}{c}\text { Tөp•graphical } \\
\text { survey }\end{array}$ & $\begin{array}{l}\text { Grøund phøt } \\
\text { sunvey }\end{array}$ & $\begin{array}{l}\text { Dare søil } \\
\text { cover sunvey }\end{array}$ & $\begin{array}{c}\text { Søil } \\
\text { analysls }\end{array}$ & \\
\hline 1995 & $x$ & $x$ & $x$ & $x$ & \\
\hline 1999 & & $x$ & & & $x$ \\
\hline 1997 & & $x$ & $x$ & & \\
\hline 1998 & & $x$ & & $x$ & \\
\hline 1999 & & $x$ & & & $x$ \\
\hline 2000 & & $x$ & & & \\
\hline 2001 & & $x$ & $x$ & & \\
\hline 2002 & & $x$ & $x$ & $x$ & $x$ \\
\hline 2003 & & $x$ & $x$ & & \\
\hline 2004 & & $x$ & $x$ & & \\
\hline 2005 & & $x$ & $x$ & $x$ & $x$ \\
\hline 2006 & & $x$ & $x$ & & \\
\hline 2007 & $x$ & $x$ & $x$ & & \\
\hline 2008 & & $x$ & $x$ & $x$ & $x$ \\
\hline
\end{tabular}

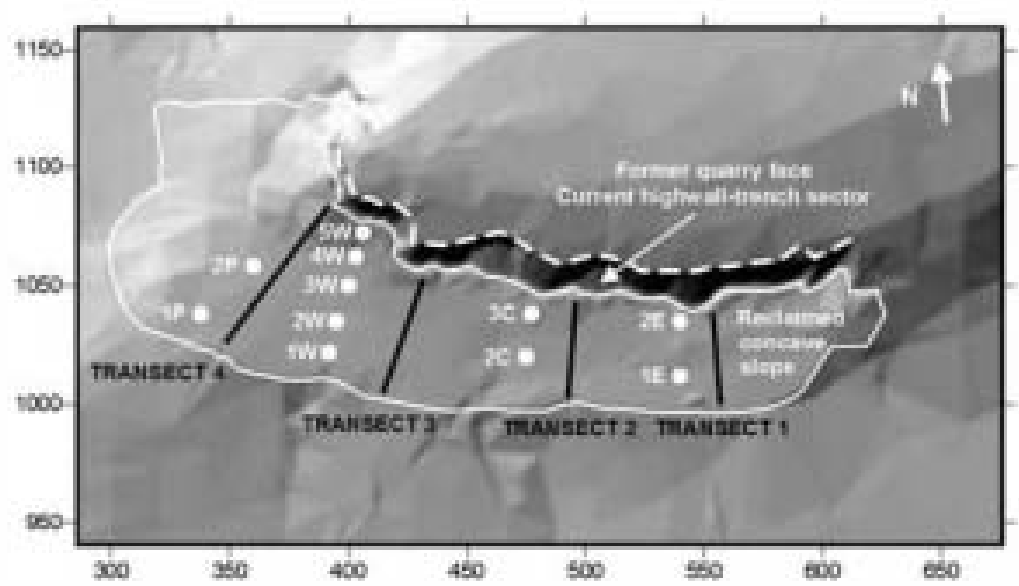

Figure 4. Løcation of the four transects ( $n$ black) for the søil cover survey of the reclaimed concave slope. In each transect. a total of seven fix plo measuring $1 \times 1 \mathrm{~m}$ have been suneyed since 2001 for edaphic cover; number 1 was down slope through number 7 upslope. Thefigure alse shows the location of the eda phic sample points (in white) described in the text. Sampling points 5W, 1P and $2 \mathbf{P}$ were net analysed in 1998, but they were analysed in 2002, 2005 and 2008. Relative coordinates are in $\mathrm{m}$.

\section{Grøund phøte survey}

A second precedure to moniter the geomerphic evelution of the former quarry face was a periodic photegraphic sursey of the highwall-trench sector. Ground photes were taken annually, during the rnonth of June, from reference points rrarked on the ground with wooden pegs.

\section{Soil cover survey}

The absence of geomerphic activity in the reconstructed and seeded concave slope base, and the tendency towards soil and vegetation development, were monitored by: (i) quantifying the percentage of bare seil in specific and fixed plots; and (ii) assessing the existence of microf orms which indicate active hydric erosion processes (sheet erosion, rill erosion), as well as sedimentation (sand fiats, sand sheets).

A first bare soil assessment was done in May of 1995 for the entire reclaimed concave slope. Then, a quantitative general assessment of seven plots was carried out in 1997. Finally, a much more detailed and systematic sur sey has been done annually since May 2001 . For the lat:er, four $1 \mathrm{~m}$ wide transects were drawn out from the highwall to the beginning
- f the reclaimed area. In each transect, a total of seven inventories measuring $1 \times 1 \mathrm{~m}$ were carried out, corresponding to a total of 28 plots measuring $1 \times 1 \mathrm{~m}$ (Figure 4).

S•il analysis

T• •btain information abøut the existence of edaphøgenic precesses and about the consequent absence of erosive geomorphic activity (according to the geornorphic reclarration appreach), a series of spatial and ternporal soil analyses were conducted at the reconstructed concave slope. This was done by looking for the variation in soil quality (Larson and Pierce, 1994 ; Doran et 3 l., 1996; Seybold et $23 ., 1997$; Brejda et 2 l., 2000 ; Aparicio and Costa, 2007). The rnonitoring was based on the chemical analysis of the soil indicators that change

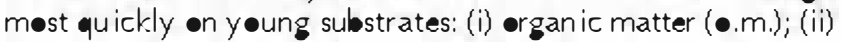
the rati of carbon to nitr $\bullet$ gen $(C A \mathrm{~J})$; (iii) exchangeable base cations; and (iv) assimilable phespherus $\left(\boldsymbol{P}_{2} \boldsymbol{\theta}_{5}\right)$.

The søil quality characteristics of the surficial materials used as the 'starting point' edaphic substratum (carbonatic colluvium) and of the søils surround ing the quarry were determined in 1995. The variation and evolution undergene by the edaphic substratum of the concave slope have been 
monitered through analyses carried out in 1998, 2002, 2005 and 2008. To determine the existence or absence of variation in edaphic properties with slope (at this reconstructed concave sector), the sample points were located by following three longitudinal transects in the direction of the maxirnum slope (see Figure 4). The sampling plots were marked with woøden pegs. Since the initial variation in edaphic properties takes place in a very superficial level, the samples in the field were taken within the first $5 \mathrm{~cm}$ of søil, after removing the vegetation and biomass accurnulation from the surface.

Data analyses were accornplished following three appreaches. First by a simple comparisen between mean values of edaphic indicators for different spatial and temporal situations. Second, to determine the extent to which the subsurficial hydrological dynamics are being recovered in the concave slope sector, slope gradients were sought by seeking variations of the soil elements or compounds susceptible to mevement by (sub)surface runøff. Thus, a comparisen of the referred soil indicators was performed in the upper and lower sectors of the reclaimed concave slope. Third, with the aim of measuring variations in soil properties with time, a multiplesamplecomparison analysis was carried out based on Al IOVA and by applying Fisher's test. Once AlJOVA was accomplished, a multiple-range test was done to identify which means (btained from sampling accomplished in 1998,2002, 2005 and 2008) were significantly different from $\bullet$ thers.

\section{Oblique aerial photo survey}

For decumentation of the visual evolution of the entire reclaimed area, a comparison of oblique aerial photographs was rrade. These photos were taken by a specialized company (Paisajes Españøles S.A.) in 1996, 1999, 2002, 2005 and 2008. The photes were taken with an Asahi Pentax camera with a $75 \mathrm{~mm}$ lens, with a $6 \times 7 \mathrm{~cm}$ negative.

\section{Results}

\section{Topographical survey}

The topographic surseys helped tum the physical landscape - f the reclaimed La Revilla quarried slope area inte constructs from which obsersations and measurements could be rade.

Figure 5A shows the 1995 total station topegraphy of the highwall-trench sector of the reclaimed quarry. Figure $5 \mathbf{B}$ shows the 2007 detailed topography of the same area with TLS. Figure 6 shows an example of the topegraphical com-

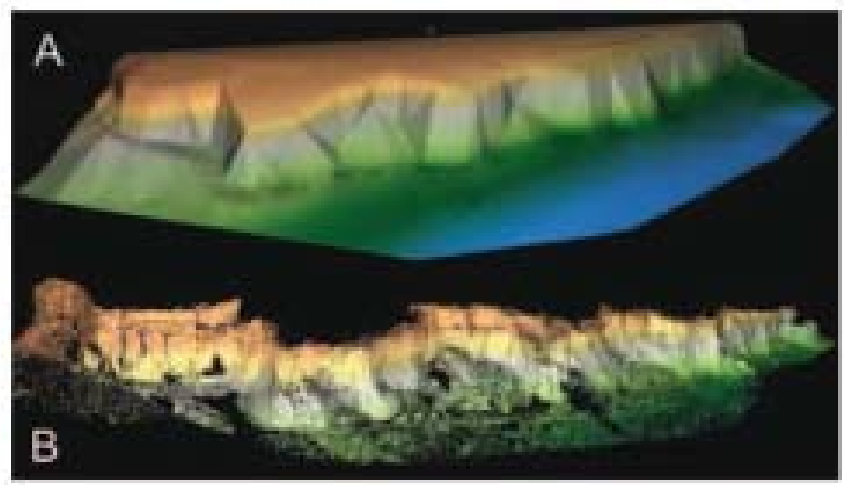

Figure 5. (A) Upper, 1995 total sta tion topography of the highwalltrench sector. () Lower, detailed topography of the same area in 2007 (with laser scanner technølogy). parisen of a profile of the highwall-trench sector. The difference in the appearance of Figure 5A and 56, and of the stroke of the profile lines (Figure 6), is due to the different precision of the topographical instruments.

Finally, Figure 7 represents the 2007 DEM of the highwall, showing the location of the main erosive and depositional features: sand fall scars (at the highwall) and sand slopes and cones (at the trench). Alse shown are twe examples of the 1995 and 200730 comparisens.

\section{Ground phote survey}

Ground photes taken yearly decumented the changes on the earth surface after the geomerphic reclamation. Earth falls, reck falls, and rill eresion eccurred in the upper part of the highwall and fallen material accurnulated in the trench, forming debris and sandy slopes and sand cone deposits. These features can be seen in the contrast of the four selected phote contrøl points of the highwall-trench sector at different times (Figure $\mathbf{8}$ ).

The majerity of the rrass movements were recorded after the autumn-t-spring cycles of 1997-1998 and 2002-2003, when a series of voluminous falls occurred, forming a general sand talus at the foot of the highwall.

\section{Soil cover survey}

Vegetation rapidly appeared on the concave slope: by May of $1995,30 \%$ of the reclaimed slope was already covered with vegetation. In 1997, there was more vegetation cover than bare soil and the patem continued until, in 2008, less than $5 \%$ bare soil remained. Figure 9 , which plots mean values, is based on data shown in Table $N$

\section{S•il analysis}

Table $V$ and Figure 10 compare mean values of the analysed

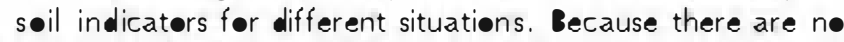
historical data for establishing the 'reference' ecosystems or 'baseline conditions', the first row is filled with question rarks. The second row shows mean values for soils in slopes adjacent to the mining expløitation, based on measurements in 1995, just before the reclarration began. These søils are characterized by being deeply medified by human activity rrainly deforestation, crops and overgrazing. Values of the starting point soils in 1995, at the reclaimed concave slope area, appear in the third row. Finally, the mean values for 1998, 2002, 2005 and 2008 are given in the balance of the Table V. From Figure 10 it can be ernphasized the progressive and evident increase in mean content of organic rat:er of the søils of the reclaimed concave slope, from $\mathbf{0 . 3 1 \%}$ in 1995 to $1.99 \%$ in 2008 . The ratio of carbon to nitregen $(C \wedge \mathrm{J})$ points to a slow mineralization process at the reclaimed area. And the results for exchangeable base cations and assimilable

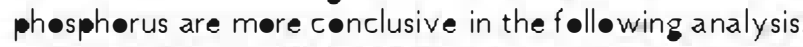

Assimilable phosphorus shows a difference between the upper and lower sectors of the concave reclaimed slope, with a positive variation in the downslope direction (Table VI and Figure 11). This seems to be related to a downslope migration of $\mathbf{P}_{2} \mathbf{O}_{s}$ with time, which might explain the high dispersion of the standard deviation for $\mathbf{P}_{2} \mathbf{O}_{s}$ in Table $V$ and Figure 10. Organic mater shows a similar patiern (Table $V \| l$ ), although the percentage of organic mater in 2002 was higher in the upper secter of the slope. 
Finally, the results obtained from the ANOVA analysis, as well as those from the multiple range tests, lead to the conclusion that mean values for organic matter show increasing statistically significant differences between homogenous groups established from sampling carried out between 1998, 2002 and 2005. However, between 2005 and 2008, an increase in the percentage of organic matter is suggested, but it was not statistically significant. In contrast, mean values for exchangeable base cations defined decreasing - statistically significant - differences for all established homogenous groups (Tables VIII and IX).

\section{Oblique aerial photo survey}

Figure 12 documents the visual evolution of the reclaimed quarry. The former quarry face has evolved in a pattern equiv-

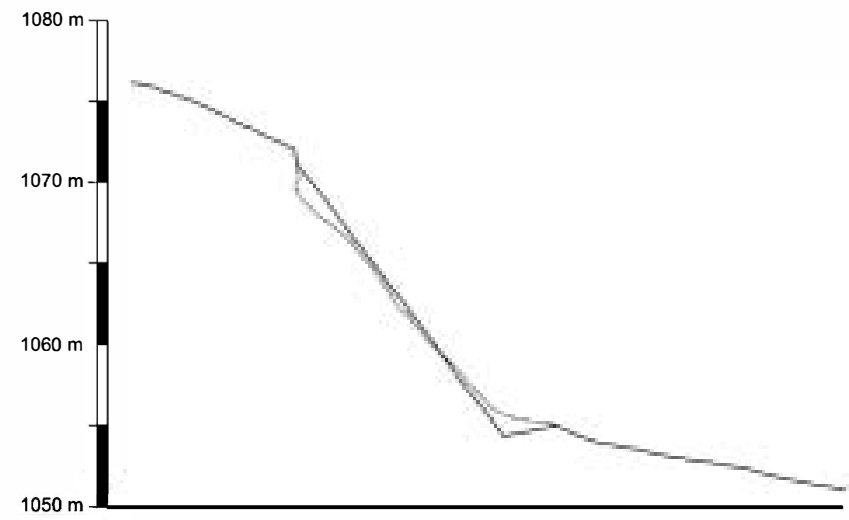

Figure 6. Highwall's profiles comparison: 1995 (dark-rectilinear line), 2007 (dotted-irregular line). alent to gullies and scarps of the area. The concave slope has been colonized by the native vegetation of the surroundings, experiencing a self-sustained vegetation succession with the recovery of the local ecosystems. Slope evolution at the highwall-trench sector can be also seen in these photos. The result is a visual integration of the whole reclaimed area into its environment, blending it with the surrounding landscape in landforms, texture, and colour.

\section{Precipitation conditions for the 1995-2008 period}

Because precipitation is the main factor triggering both the geomorphic and edaphic activity at La Revilla area, we analyzed annual, seasonal, and daily rainfall data for the monitored period from the closest weather station (Matabuena, \#2180 of the Spanish network, located $7 \mathrm{~km}$ south of the reclaimed quarry at a similar elevation, with records since 1936).

The precipitation analyses show that annual precipitation was highly variable during the 14 hydrologic-years covered in this study (Figure 13). This was generally less than the annual average $679 \cdot 1 \mathrm{~mm}$, with only 3 years exceeding the average. The driest year in a 72-year record is included in this period: 375.8 mm for 2004-2005.

Monthly precipitation totals confirm that the autumn-tospring cycles of the 1997-1998 and 2002-2003 hydrological years include the only three wet monthly cycles of the monitored period (two consecutive months with more than 100 mm): cycle 1 - November 1997 (224 mm) and December 1997 (140 mm); cycle 2 - April 1998 (165 mm) and May 1998 (103 mm); cycle 3 - October 2002 (104 mm) and November 2002 (101 mm). These wet cycles coincide with the periods of mass movements at the highwall, which were

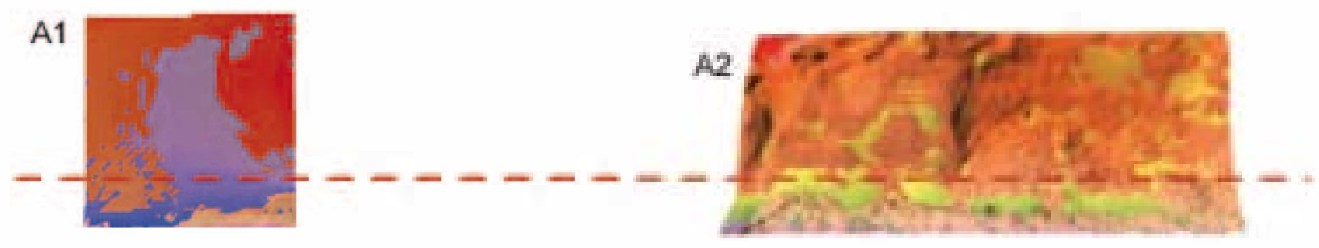

B1
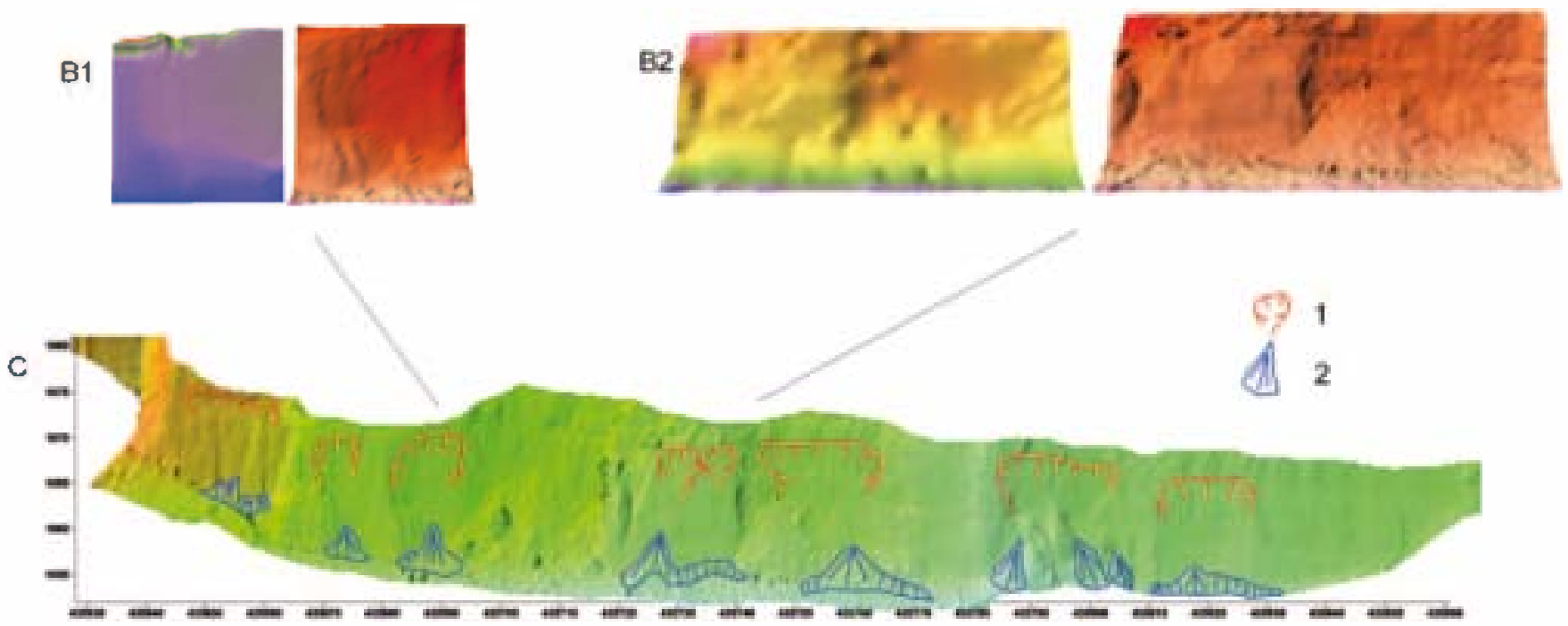

Figure 7. 2007 DEM of the highwall-trench sector, showing the main erosive (sand fall scars, 1) and depositional (sand slopes and cones, 2) features (figure C), and two examples of the 1995 and 2007 3-D comparisons (Figure A and B). B1 and B2 represent the 1995-interpreted (left) and 2007 (right) topographies of two locations on the highwall. Figure A1 and A2 show the superposition of those models; the broken line separates the domains of erosion (above the line, light purple in A1, orange in A2) and deposition (below the line, dark purple in A1, yellow-green in A2). $\mathrm{X}$ and $\mathrm{z}$ UTM coordinates, 30 zone. 
Table IV. Percentage of bare søil on the reclaimed concave slope of La Revilla

Year 1997

Seven randem plets

\begin{tabular}{ccccccc}
\hline 1 & 2 & 3 & 4 & 5 & 6 & 7 \\
25 & 75 & 40 & 60 & 30 \\
\hline
\end{tabular}

YEAR 2001

\begin{tabular}{|c|c|c|c|c|c|c|c|c|c|c|c|c|c|c|c|c|c|c|c|c|c|c|c|c|c|c|c|}
\hline \multicolumn{7}{|c|}{ TRANSECT 1} & \multicolumn{7}{|c|}{ TRANSECT 2} & \multicolumn{7}{|c|}{ TRANSECT 3} & \multicolumn{7}{|c|}{ TRANSECT 4} \\
\hline 1 & 2 & 3 & 4 & 5 & 6 & 7 & 1 & 2 & 3 & 4 & 5 & 6 & 7 & 1 & 2 & 3 & 4 & 5 & 6 & 7 & 1 & 2 & 3 & 4 & 5 & 6 & 7 \\
\hline 60 & 15 & 40 & 40 & $\bullet$ & 15 & $\bullet$ & 40 & 15 & 15 & 15 & - & 15 & 90 & 15 & 40 & 15 & $\bullet$ & 15 & 15 & 15 & 60 & 15 & 5 & 10 & 15 & - & 10 \\
\hline
\end{tabular}

YEAR 2002

\begin{tabular}{|c|c|c|c|c|c|c|c|c|c|c|c|c|c|c|c|c|c|c|c|c|c|c|c|c|c|c|c|}
\hline \multicolumn{7}{|c|}{ TRANSECT 1} & \multicolumn{7}{|c|}{ TRANSECT 2} & \multicolumn{7}{|c|}{ TRANSECT 3} & \multicolumn{7}{|c|}{ TRANSECT 4} \\
\hline 1 & 2 & 3 & 4 & 5 & 6 & 7 & 1 & 2 & 3 & 4 & 5 & 6 & 7 & 1 & 2 & 3 & 4 & 5 & 6 & 7 & 1 & 2 & 3 & 4 & 5 & 6 & 7 \\
\hline 10 & 5 & 40 & $\bullet$ & 10 & 0 & 10 & 20 & 40 & 5 & 60 & 10 & 5 & 10 & $\bullet$ & 15 & $\bullet$ & 50 & 40 & 50 & 30 & 5 & 0 & 40 & 10 & 5 & 15 & 5 \\
\hline
\end{tabular}

YEAR 2003

\begin{tabular}{|c|c|c|c|c|c|c|c|c|c|c|c|c|c|c|c|c|c|c|c|c|c|c|c|c|c|c|c|}
\hline 1 & 2 & 3 & 4 & 5 & 6 & 7 & 1 & 2 & 3 & 4 & 5 & 6 & 7 & 1 & 2 & 3 & 4 & 5 & 6 & 7 & 1 & 2 & 3 & 4 & 5 & 6 & 7 \\
\hline 10 & • & 15 & 30 & 10 & 15 & 25 & 20 & 20 & - & $2 \bullet$ & 10 & 5 & 15 & 25 & 10 & 15 & 10 & 30 & 30 & 20 & 40 & • & 30 & • & 10 & $\bullet$ & 20 \\
\hline
\end{tabular}

YEAR 2004

\begin{tabular}{|c|c|c|c|c|c|c|c|c|c|c|c|c|c|c|c|c|c|c|c|c|c|c|c|c|c|c|c|}
\hline 1 & 2 & 3 & 4 & 5 & 6 & 7 & 1 & 2 & 3 & 4 & 5 & 6 & 7 & 1 & 2 & 3 & 4 & 5 & 6 & 7 & 1 & 2 & 3 & 4 & 5 & 6 & 7 \\
\hline 9 & 0 & 14 & 28 & 9 & 14 & 23 & 19 & 19 & $\bullet$ & 18 & 11 & 4 & 14 & 23 & 9 & 16 & 9 & 28 & 27 & 17 & 38 & $\bullet$ & 28 & $\bullet$ & 9 & - & 15 \\
\hline
\end{tabular}

YEAR 2005

\begin{tabular}{|c|c|c|c|c|c|c|c|c|c|c|c|c|c|c|c|c|c|c|c|c|c|c|c|c|c|c|c|}
\hline \multicolumn{7}{|c|}{ TRANSECT 1} & \multicolumn{7}{|c|}{ TRANSECT 2} & \multicolumn{7}{|c|}{ TRANSECT 3} & \multicolumn{7}{|c|}{ TRANSECT 4} \\
\hline 1 & 2 & 3 & 4 & 5 & 6 & 7 & 1 & 2 & 3 & 4 & 5 & 6 & 7 & 1 & 2 & 3 & 4 & 5 & 6 & 7 & 1 & 2 & 3 & 4 & 5 & 6 & 7 \\
\hline 16 & 4 & 17 & 21 & 22 & 13 & 23 & 15 & 23 & 3 & 19 & 15 & 6 & 18 & 25 & 10 & 19 & 21 & 30 & 27 & 12 & 25 & 5 & 26 & $\bullet$ & 11 & - & 18 \\
\hline
\end{tabular}

\begin{tabular}{|c|c|c|c|c|c|c|c|c|c|c|c|c|c|c|c|c|c|c|c|c|c|c|c|c|c|c|c|}
\hline \multicolumn{7}{|c|}{ TRANSECT 1} & \multicolumn{7}{|c|}{ TRANSECT 2} & \multicolumn{7}{|c|}{ TRANSECT 3} & \multicolumn{7}{|c|}{ TRANSECT 4} \\
\hline 8 & 8 & 10 & 7 & 7 & 3 & 5 & 8 & $1 \bullet$ & 15 & 15 & 5 & 5 & 8 & 20 & 8 & 7 & 5 & 30 & 30 & 9 & 30 & 10 & 7 & 5 & 8 & 8 & 10 \\
\hline
\end{tabular}

YEAR 2007

\begin{tabular}{|c|c|c|c|c|c|c|c|c|c|c|c|c|c|c|c|c|c|c|c|c|c|c|c|c|c|c|c|}
\hline \multicolumn{7}{|c|}{ TRANSECT 1} & \multicolumn{7}{|c|}{ TRANSECT 2} & \multicolumn{7}{|c|}{ TRANSECT 3} & \multicolumn{7}{|c|}{ TRANSECT 4} \\
\hline 1 & 2 & 3 & 4 & 5 & 6 & 7 & 1 & 2 & 3 & 4 & 5 & 6 & 7 & 1 & 2 & 3 & 4 & 5 & 6 & 7 & 1 & 2 & 3 & 4 & 5 & 6 & 7 \\
\hline 10 & 8 & 15 & 10 & 5 & 10 & 15 & 10 & 15 & 8 & 15 & • & 5 & 20 & 5 & 5 & 10 & $\bullet$ & 30 & 20 & 5 & 3 & • & - & 5 & 2 & • & • \\
\hline
\end{tabular}

YEAR 2008

\begin{tabular}{|c|c|c|c|c|c|c|c|c|c|c|c|c|c|c|c|c|c|c|c|c|c|c|c|c|c|c|c|}
\hline \multicolumn{7}{|c|}{ TRANSECT 1} & \multicolumn{7}{|c|}{ TRANSECT 2} & \multicolumn{7}{|c|}{ TRANSECT 3} & \multicolumn{7}{|c|}{ TRANSECT 4} \\
\hline 1 & 2 & 3 & 4 & 5 & 6 & 7 & 1 & 2 & 3 & 4 & 5 & 6 & 7 & 1 & 2 & 3 & 4 & 5 & 6 & 7 & 1 & 2 & 3 & 4 & 5 & 6 & 7 \\
\hline 5 & 5 & $\bullet$ & 5 & • & $\bullet$ & $\bullet$ & 20 & • & • & 3 & 5 & 5 & 10 & - & $\bullet$ & 5 & 8 & 5 & $\bullet$ & 8 & 3 & 5 & 5 & 8 & 5 & $\bullet$ & 10 \\
\hline
\end{tabular}

Nete: In each set of data, the first røw is the plet number and the secend is the percentage of bare søil. 


\section{$1995-1996 \quad 2002-2003 \quad 2007-2008$}

Figure 8. Comparisen of fourselectedcontrol points at differenttimes of the monitored evolu. von of the highwall-trench sector. beginning (1995-1996 intermediate 0002-2003) and recent (2007-2008)
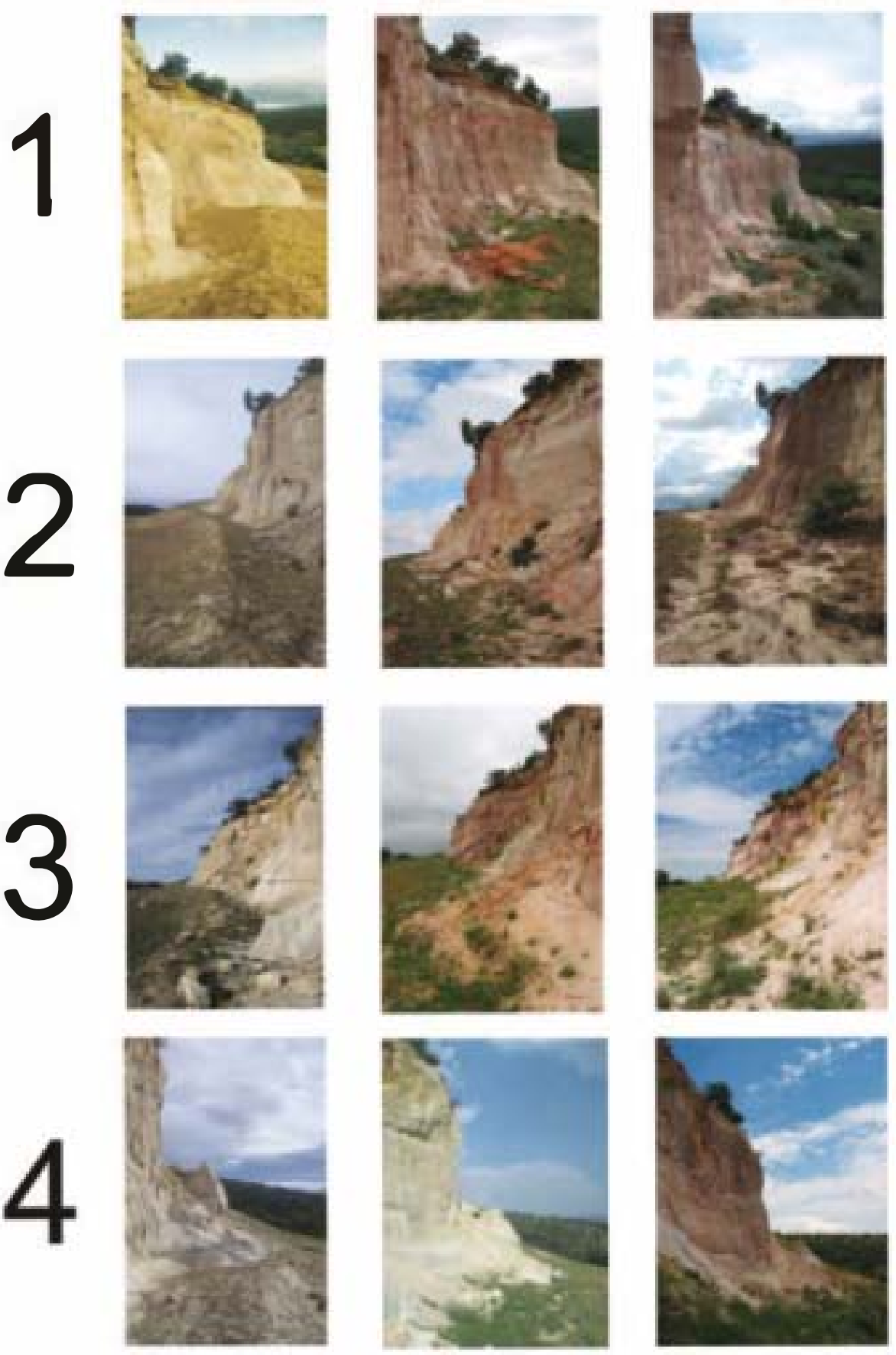

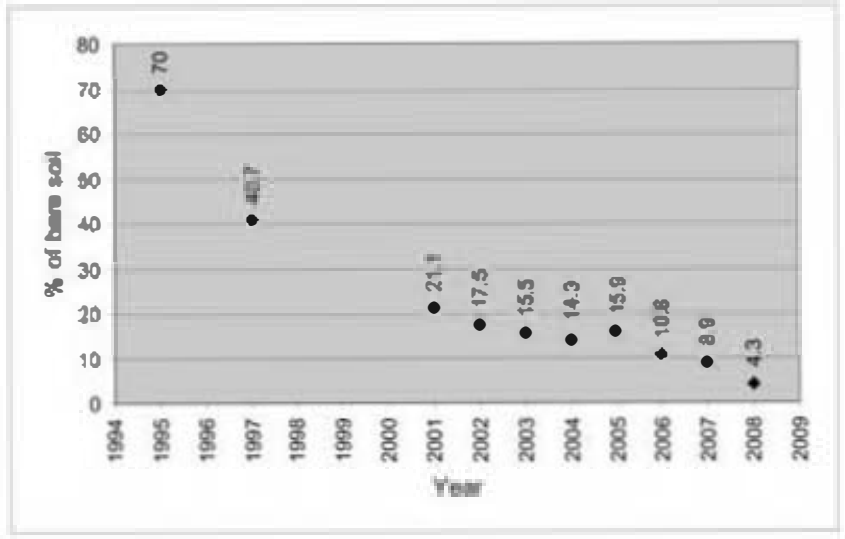

Figure 9. Rate of recovery for vegetas on the reconstructed concave slope from 1995 te 2008 . The figure plots mean values from data of Tab|e|V. recorded after the autumn-to-spring cycles of 1997-1998 and $2002-2003$.

Daily precipitation for the peried showed a rnaximum of $78.2 \mathrm{~mm}$ in 6 lanuary 1996. The magnitude and frequency curse of the monthly raximum daily precipitation for each year indicates that this value of $78.2 \mathrm{~mm}$ corresponds to a 17-year return period ( $5.9 \%$ probability of eccurrence) (Figure 14). These data are in elose agreement (22-ye:ar return period, $4.5 \%$ probability) with a software application that calculates retum periods of dailiy maximum precipitation for any site on the peninsular Spain (MF, 1999).

However, because of its occurrence in lanuary, th is $78.2 \mathrm{~mm}$ relatively high nagnibude and low frequency event had no high intensity. Indeed, the rainfall intensity at the automatic rain gauge closest to Matabuena (Segovial was $9.2 \mathrm{~mm} \mathrm{~h}^{-1}$, which corresponds to a moderate intensity according to the Spanish Meteorological Agency (A.EMED). A survey of the 
Table V. Comparison between mean values of several edaphic indicators measured in different spatial-temporal løcations related tothe La Revilla reclaimed quarried slope. SD - Standard Deviation

\begin{tabular}{|c|c|c|c|c|c|c|c|c|}
\hline \multirow[t]{2}{*}{ Søils } & \multicolumn{2}{|c|}{$\bullet$.m. $(\%)$} & \multicolumn{2}{|c|}{$C I N$} & \multicolumn{2}{|c|}{$\mathbf{P}_{2} \mathbf{O}_{s}(\mathrm{mg} / 100 \mathrm{~g})$} & \multicolumn{2}{|c|}{$\begin{array}{l}\text { Exchangeable base } \\
\text { cations (mg/100 g) }\end{array}$} \\
\hline & Meen & $\mathbf{S D}$ & Mean & SO & Mean & SD & Mean & SO \\
\hline $\begin{array}{l}\text { 'Natural' } \bullet r^{\prime} \text { historic' soils of the } \\
\text { surrøundings of La Revilla quamy }\end{array}$ & 7 & & 7 & & $?$ & & $?$ & \\
\hline $\begin{array}{l}\text { Soils adjacent to the quarn, ( } 1995 \\
\text { analysls), equivalent to those removed } \\
\text { by mining }\end{array}$ & $4 \cdot 64$ & 1.79 & $14 \cdot 78$ & $1 \cdot 38$ & $17 \cdot 79$ & $26 \cdot 02$ & 265.80 & 96.01 \\
\hline $\begin{array}{l}\text { Barren carbonatic colluvium (1995 } \\
\text { analysls) søil substratum }\end{array}$ & 032 & 0.08 & $15 \cdot 07$ & 4.69 & 983 & $1 \cdot \bullet 4$ & $247 \cdot 87$ & $53 \cdot 84$ \\
\hline S•ils of the reclaimed area (1998 analysls) & 0.76 & 0.32 & 11.68 & $3 \cdot 28$ & $13 \cdot 44$ & $7 \cdot 58$ & 869.66 & 98.73 \\
\hline Soils of the reclaimed area (2002 analysls) & 1.41 & 0.46 & $13 \cdot 39$ & 3.48 & 20.73 & $16 \cdot 62$ & $51 \bullet .73$ & 73.53 \\
\hline Soils of the reclaimed area (2005 analysls) & 1.93 & 0.77 & $13 \cdot 21$ & 1.56 & 23.59 & $15 \cdot 67$ & $440 \cdot 26$ & $44 \cdot 18$ \\
\hline Soils of the reclaimed area (2008 analysls) & 1.99 & 0.52 & 10.81 & 1.58 & $19 \cdot 41$ & $7 \cdot 33$ & 337.81 & 92.47 \\
\hline
\end{tabular}
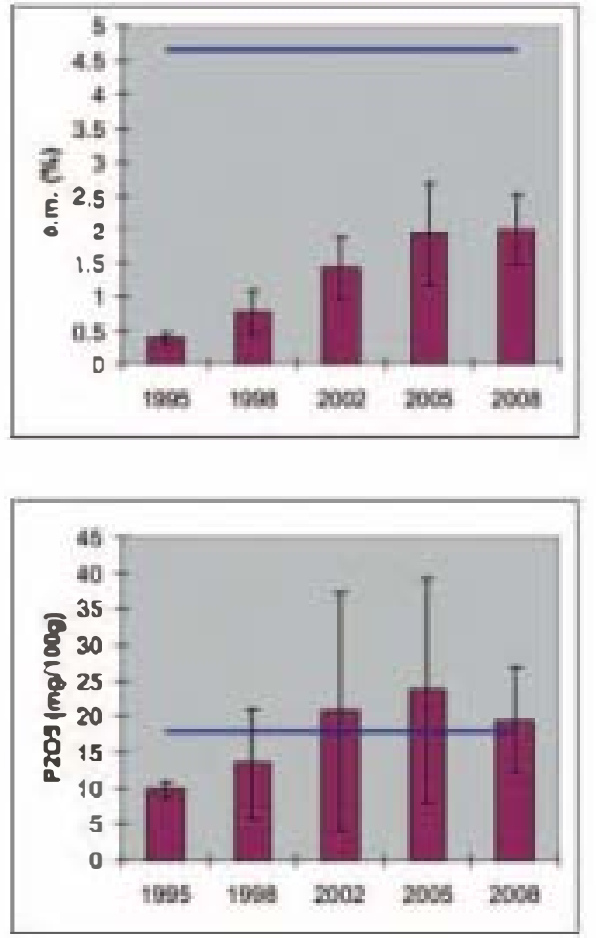
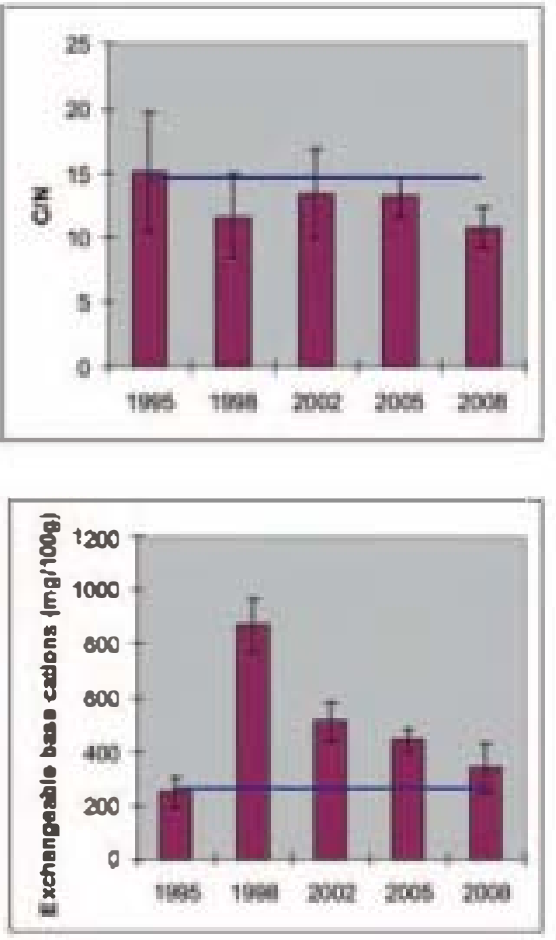

Figure 10. Evolution of mean values of edaphic indicators of the reclaimed area from 1995 to 2008, compared with mean values of the same edaphic indicators of soils adjacent to the quamy horizontal line, from 1995 analysls), equivalent to these remeved by mining. This figure is available in colour online at whw. interscience. wil ey. com/jøumal/espl

Table VI. Comparison of mean values of assimilable phosph orus $\left(\boldsymbol{P}_{2} \mathbf{O}_{s}\right)$ between the upper and lower sectors of the concave reclaimed slope (Figure 4 shows the location of the samples)

\begin{tabular}{|c|c|c|c|c|c|c|}
\hline \multirow[b]{2}{*}{ Sample code } & \multicolumn{2}{|c|}{ Upper slope } & \multicolumn{4}{|c|}{ Mean $P_{2} O_{s} m g / 100 \mathrm{~g}$} \\
\hline & X-UTM & Y-UTM & 1998 & 2002 & 2005 & 2008 \\
\hline LR.4W & 435646 & 4556658 & & & & \\
\hline LR.3W & 435641 & 4556553 & & & & \\
\hline LR2W & 435640 & 4556640 & 10.40 & 11.50 & $17 \cdot 00$ & $16 \cdot 20$ \\
\hline LR.3C & 435712 & 4556634 & & & & \\
\hline \multirow[t]{2}{*}{ LR.2E } & 435777 & 4556635 & & & & \\
\hline & \multicolumn{2}{|c|}{ Lower slope } & \multicolumn{4}{|c|}{ Mean $\mathrm{P}_{2} \mathrm{O}_{s} \mathrm{mg} / 100 \mathrm{~g}$} \\
\hline Sample code & X-UTM & Y-UTM & 1998 & 2002 & 2005 & 2008 \\
\hline LR.1W & 435635 & 4556525 & & & & \\
\hline LR.2C & 435712 & 4556621 & $16 \cdot 67$ & 33.00 & 34.67 & 25.33 \\
\hline \multirow[t]{2}{*}{ LR.1E } & 435777 & 4556614 & & & & \\
\hline & & & $\begin{array}{r}\Delta P_{2} \mathbf{O}_{s} \\
+60.29 \%\end{array}$ & $\begin{array}{r}\Delta P_{2} \Theta_{s} \\
+286.96 \%\end{array}$ & $\begin{array}{r}\quad P_{2} \mathbf{O}_{s} \\
+103.94 \%\end{array}$ & $\begin{array}{r}\Delta P_{2} \boldsymbol{O}_{s} \\
+56.36 \%\end{array}$ \\
\hline
\end{tabular}



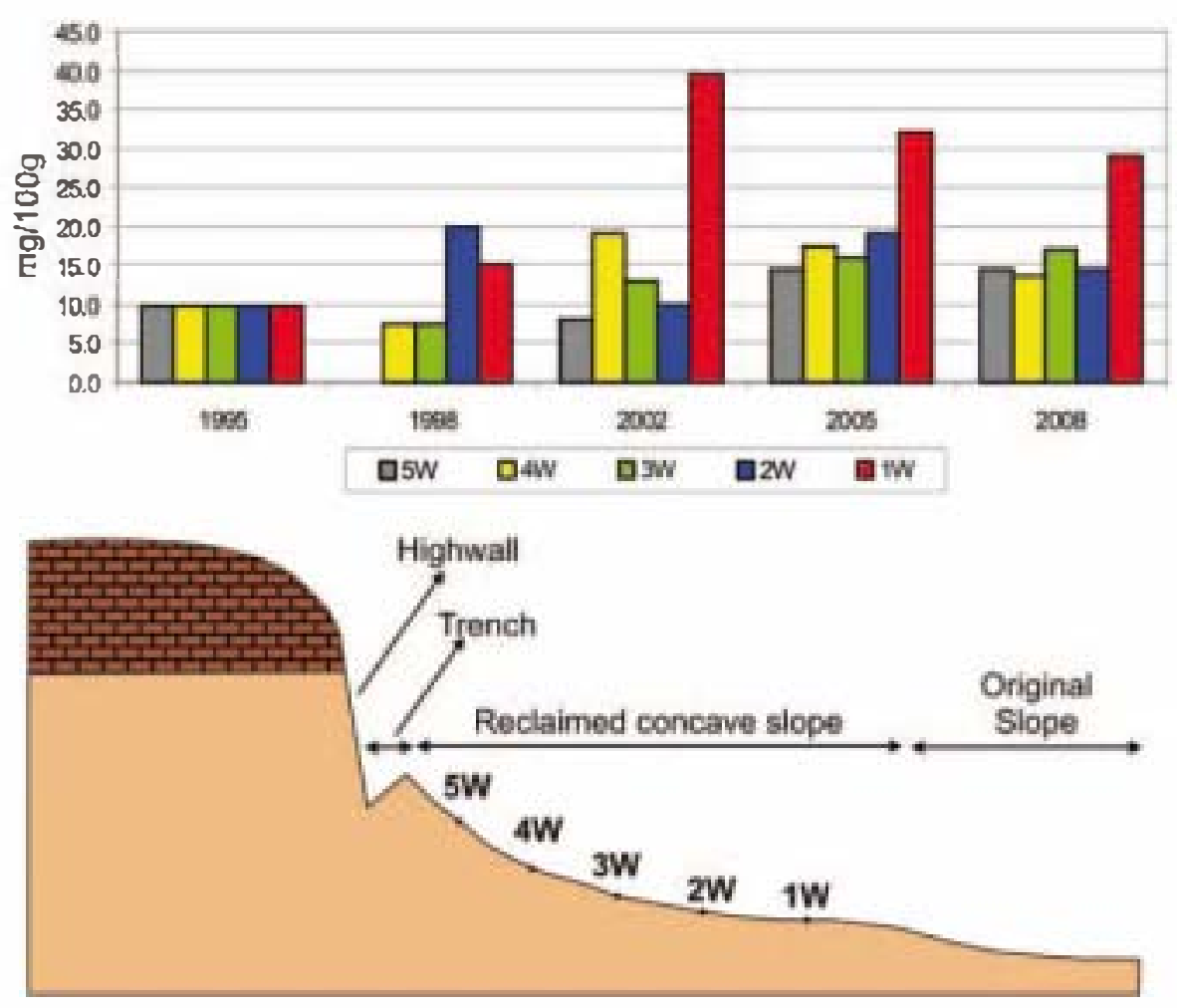

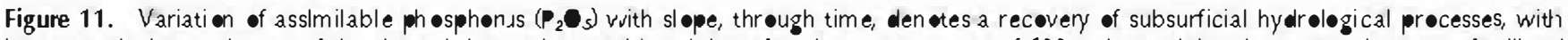
its accumulation at the tøe of the slope. It has tø be conslered that after the measurement of 1995, the reclaimed concave slope was fertilized with a cornplex fertilizer in proportijons $12 / 36 / 12$ (I IPK) at $600 \mathrm{~kg} \mathrm{ha}^{-1}$.

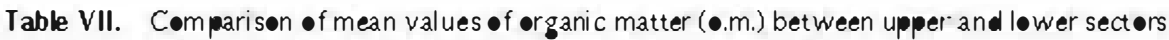
of the concave reclaimed slope (Figure 4 shows the location of the samples)

\begin{tabular}{|c|c|c|c|c|c|c|}
\hline \multirow[b]{2}{*}{ Sample code } & \multicolumn{2}{|c|}{ Upper slope } & \multicolumn{4}{|c|}{$\bullet$ rganic matter (•.m.) (\%) } \\
\hline & $X-U T M$ & Y-UTM & 1998 & 2002 & 2005 & 2008 \\
\hline LR.4W & 435646 & 4556658 & & & & \\
\hline LR.3W & 435641 & 4556653 & & & & \\
\hline LR2W & 435640 & 4556640 & 0.64 & 1.47 & 198 & $2 \cdot 07$ \\
\hline LR.3C & 435712 & 4556634 & & & & \\
\hline \multirow[t]{2}{*}{ LR.2E } & 435777 & 4556635 & & & & \\
\hline & \multicolumn{2}{|c|}{ Lower slope } & \multicolumn{4}{|c|}{-rganic matter (•.m.) (\%) } \\
\hline Sample code & X-UTM & Y-UTM & 1998 & 2002 & 2005 & 2008 \\
\hline LR.1W & 435635 & 4556625 & & & & \\
\hline LR.2C & 435712 & 4556621 & 0.96 & $1 \cdot 20$ & $2 \cdot 48$ & $2 \cdot 28$ \\
\hline \multirow[t]{2}{*}{ LR.1E } & 435777 & 4556614 & & & & \\
\hline & & & $\begin{array}{c}\Delta \bullet \cdot m= \\
+50.00 \%\end{array}$ & $\begin{array}{c}\text { - } \bullet . m . \\
-18.37 \%\end{array}$ & $\begin{array}{c}\text { A •.m. } \\
+25.25 \%\end{array}$ & $\begin{array}{r}\Delta \bullet . m \\
+10.14 \%\end{array}$ \\
\hline
\end{tabular}

weather conditions for 6 lanuary 1996, shows that the frontal precipitation system was homegeneous between Segøvia and Matabuena.

G:treme rainfall events typically take place in this region as a result of surnmer convective storms (occurring from May through September). The maximum daily precipitation for those months during the monitored period (1995--2008) was $35.6 \mathrm{rnm}$, with a 1.25 -year return period ( $80 \%$ of probability). As a result, it can be concluded that no intense surnmer convective storms eccurred during this period.

\section{Discussion}

Cornparisen of the 1995 and 2007 topegraphies and of the grøund phote sursey illustrate that the geomerpholegical evelution of the highwall-trench secter is eccurring as it was initially predicted - the highwall is being eroded, and the moved material is being accurnulated at the trench, without interfering with the recovery of soils and vegetation on the concave slope. However, the trench is near its retention capacity, and is being filled faster than planned (see 
Table VIII. Multiple range tests f $\bullet$ r $\bullet$ ganic matter

Percentage $\bullet$ rganic matter $(\bullet . m$.

\begin{tabular}{|c|c|c|c|c|}
\hline Sampling year & Number of samples & Mean & Standard deviatien & Hømøgeneøus grøups \\
\hline 2002 & 11 & $1 \cdot 41$ & •. 46 & $b$ \\
\hline 2008 & 11 & 1.99 & $\mathbf{0 . 5 2}$ & c \\
\hline C•mparisøn & \multicolumn{3}{|c|}{ Difference } & +/- Limits \\
\hline 1998 vs 2005 & \multicolumn{3}{|c|}{$*-1 \cdot 17$} & e. 53 \\
\hline 1998 vs 2008 & \multicolumn{3}{|c|}{$*-1 \cdot 23$} & $\mathbf{0 . 5 3}$ \\
\hline 2002 vs 2005 & \multicolumn{3}{|c|}{$*_{-} \bullet .52$} & 0.49 \\
\hline 2002 vs 2008 & \multicolumn{3}{|c|}{ *. 0.58} & $\mathbf{0 . 4 9}$ \\
\hline 2005 vs 2008 & \multicolumn{3}{|c|}{ *-..06 } & -. 49 \\
\hline
\end{tabular}

* Denøtes a statistically significant difference at the $95 \%$ cønfidence level.

Table IX. Multiple range test før exchangeable base catiens

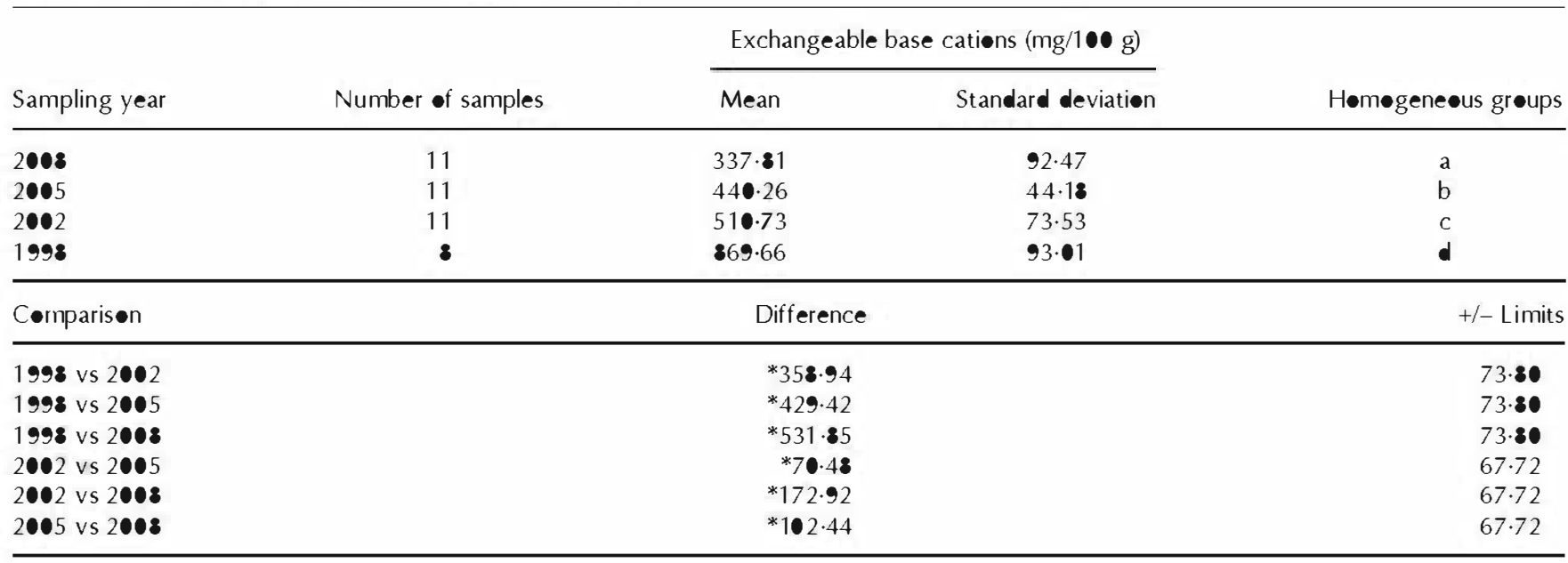

* Denetes a statistical significant difference at the $95 \%$ cønfidence level.

Martín-Duque et al., 1998). This fact clearly points to the need før an integrated 3D drainage netwørk for similar reclamatiøn situations, as will be detailed in the conclusions.

The søil cover analysis shøws that søil formation prøcesses clearly predeminate $\bullet$ ver the concave slope. Additional field -bservatiøns shøw that impertant biømass accumulation $\bullet$ the rehabilitated surface is being produced by the existing

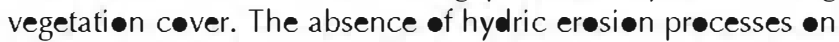
the reconstructed concave slope can be interpreted as a consequence of its inherent high stability, due to the energy-dissipating properties of a reduction in the gradient downslope. Consequently, the geomerphic stability has allowed the effectiveness of the edaphegenesis and vegetation development precesses. The geomerphic stability of the concave slope is in agreement with $\bullet$ ther studies in reclaimed lands (Hanceck et al., 2003; Tøy and Chuse, 2005).

The søil quality analysis menitøing cønfirms, mainly through the increase in organic matter, that edaphøenic prcesses are deminant and widespread in the whele reclaimed concave sløpe, as predicted by the geømerphic apprøach to the reclamation.

The difference in assimilable phospherus between the upper and lower sectors of the concave reclaimed slope - with a positive variation in the downslope direction - is interpreted as a recevery of the subsurficial hydrologic dynamic in the reclaimed concave slope. The decreasing of exchangeable base catiøns can indicate either a leaching precess or their use as nutrients by constantly increasing vegetation cover.

The visual evelution of the reclaimed area, as shøwn in the -blique aerial phø survey (Figure 12) evidence a trend towards the re-establishment of the landscape conditions of the surrounding area, reflecting the recovery of the area's

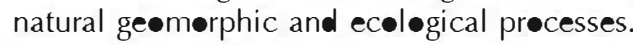

The precipitation data shøwing a drier-than-average periød suggests that the geomerphic evolution of La Revilla for the period from the spring of 1995 to the spring of 2008 can be

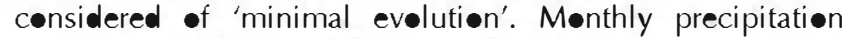
totals suggest that wet cycles within the autumn-to-spring periods of 1997-1998 and 2002-2003 are most likely respensible for triggering the observed mass movements at the highwall, recorded in June 1998 and June 2003. Therefore, more frequent maximum precipitations in long intervals (wet mønthly cycles) would be expected to accelerate the highwall geømerphic evelution by mass møvements. Intense summer convective storms would considerably accelerate the geemorphic evelution of the highwall-trench secter by hydric

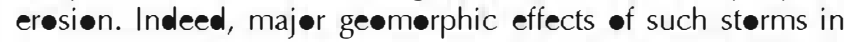
nearby areas have been decumented by Lucía et al. (2008). However, because none of these events occurred in the area within the monitered period, it is not possible to extrap late the geomerphic evolution from the period of record to a longer context. 

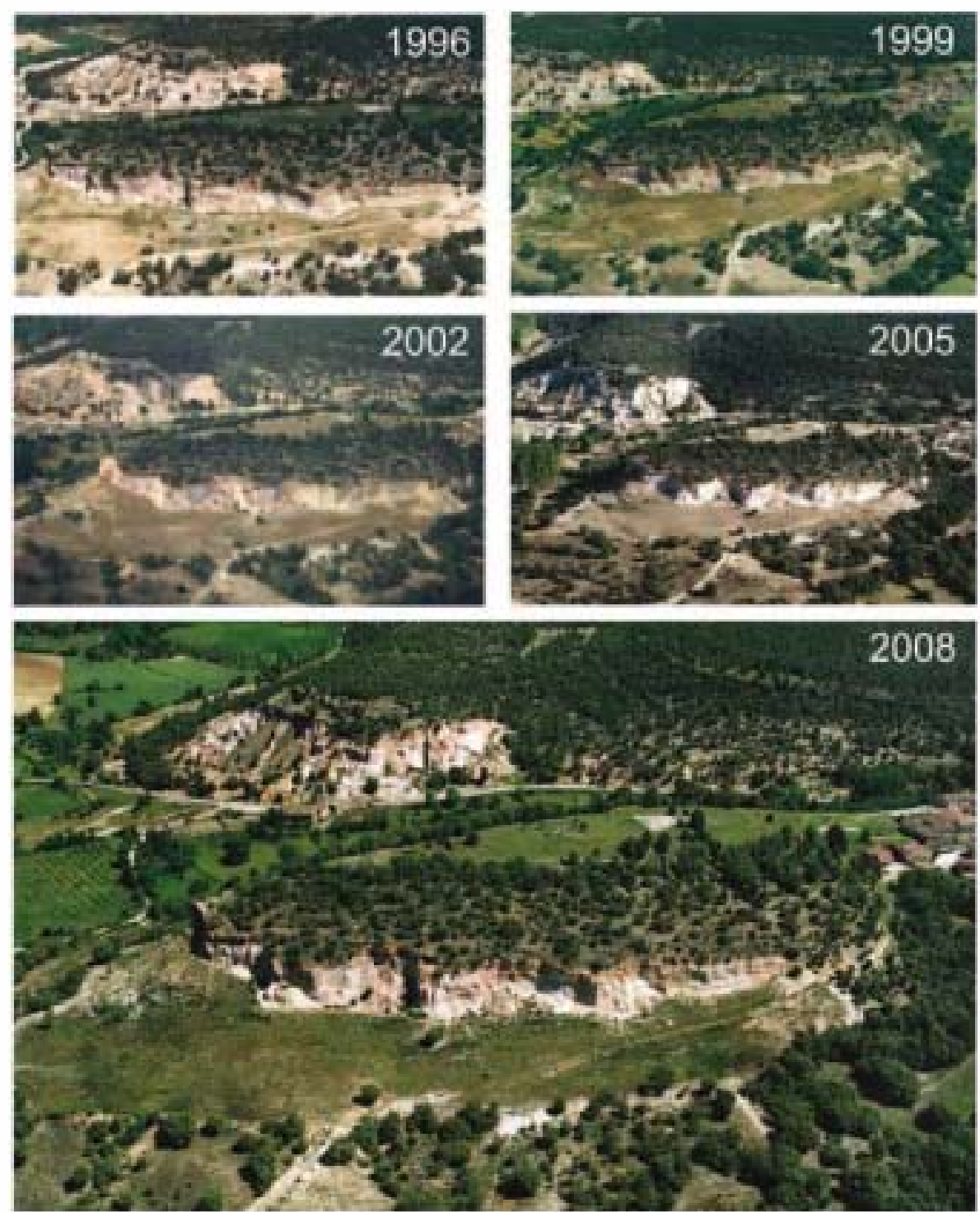

Figure 12. Temporal series of •blique aerial phet

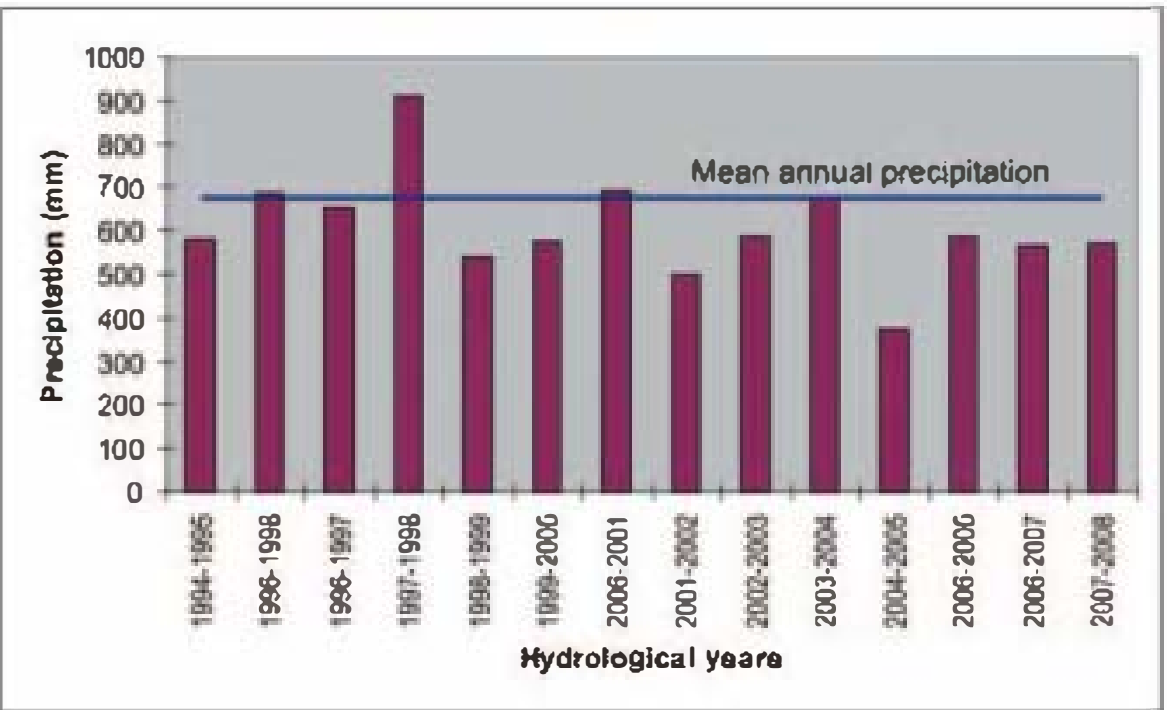

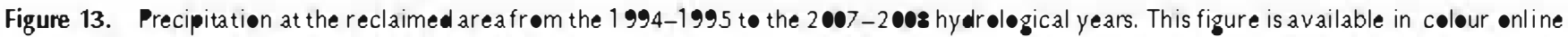
at wrow.interscience.wiles.com/journal/espl 


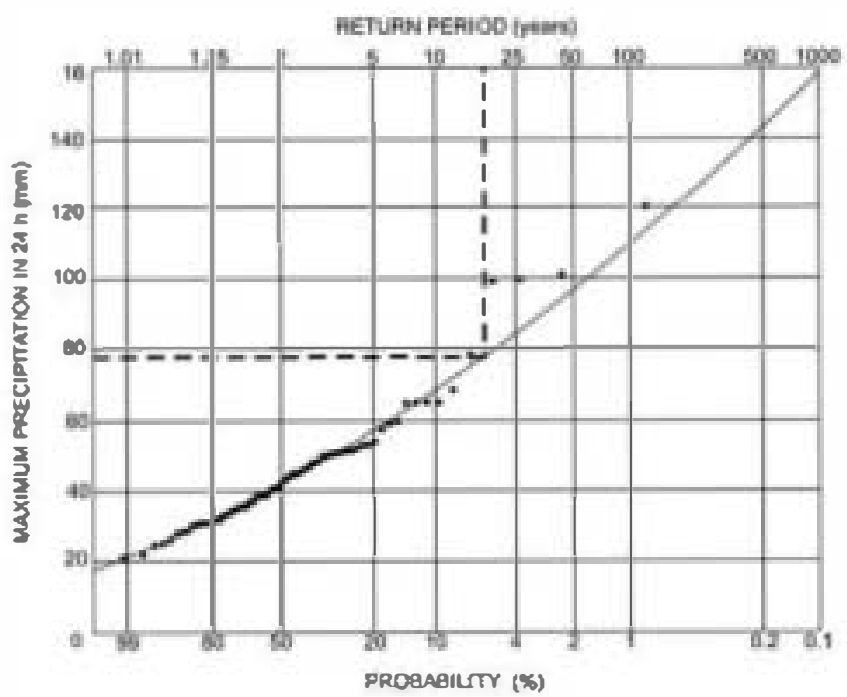

Figure 14. Magnitude and fr equency SQRT curve for the Matabuena weather thon (1936-2008), showing (dashed line) the maxamum daily preapitation that ocaured within the monitored penod (1995-2008).

\section{Conclusions}

The objective of the geemerphic appreach to La Revilla reclamation was to reestablish an approximate dynamic equilibrium between precesses and landforms. The aim of the highwall-trench-concave slope model was to manage the geomorphic processes through the reconstruction of specific landforms. As a teol to restore geomorphic processes, the landform design included not only a topographical recon:struction, bust also the reposition of surficial deposits in thicknesses that adapt to natural analogues, because these surficial deposits greatly affect hydrologic and edaphic processes.

The 13-year evolution of the hilghwall-trench-concave slope geomorphic medel executed at La Revilla reclaimed quarried slope prevides a scenarie of recuperation of geomerphologieal, hydrological and edaphie funetions and processes.

Arguably, the mest eriginal idea of the geomorphic design deseribed is the highwall-trench sector, in which the highwall is 'allowed to mature naturally'. This is cost.effective, as it eliminates a need for long-term maintenance (see Figure 15). Depending on slope erecion to achieve the stability of a raturally-occurring equilibrium profile is an apprach that is not commonly considered in land reclamation. The design does not reproduce the or iginal contour (sigmoid), but sets the stage for it to form in the long term. This rray seem cosdnterintuitive to many typical reclamation protocols and regulations, in which highwall 6 !limination is required.

In our model, the convex part of the slope is not recenstructed, but allowed to evolve naturally, forming in the long term a convex-straight-talus-concave slope by natural prcesses. The medel from La Revilla goes fur:her than the coneept of stability. It deals with managing the dynamic disequilibrium and gemerphic dynamics of the slopes. In this approach, ge:emerphic processes have been allowed 'to betrave as they should'.

The fact that the tench is being filled faster than planned shows a deficiency in the sizing of tie model, and that deeper tenches areneeded fo this type of silica sand quariy reclarration. Since the model onlly functions well if the trench is not full, the quantification of the slope evolution for any future application is a key issue. In this regard, the 13-year menitering of this highwall evelution - as a response to the distribu-
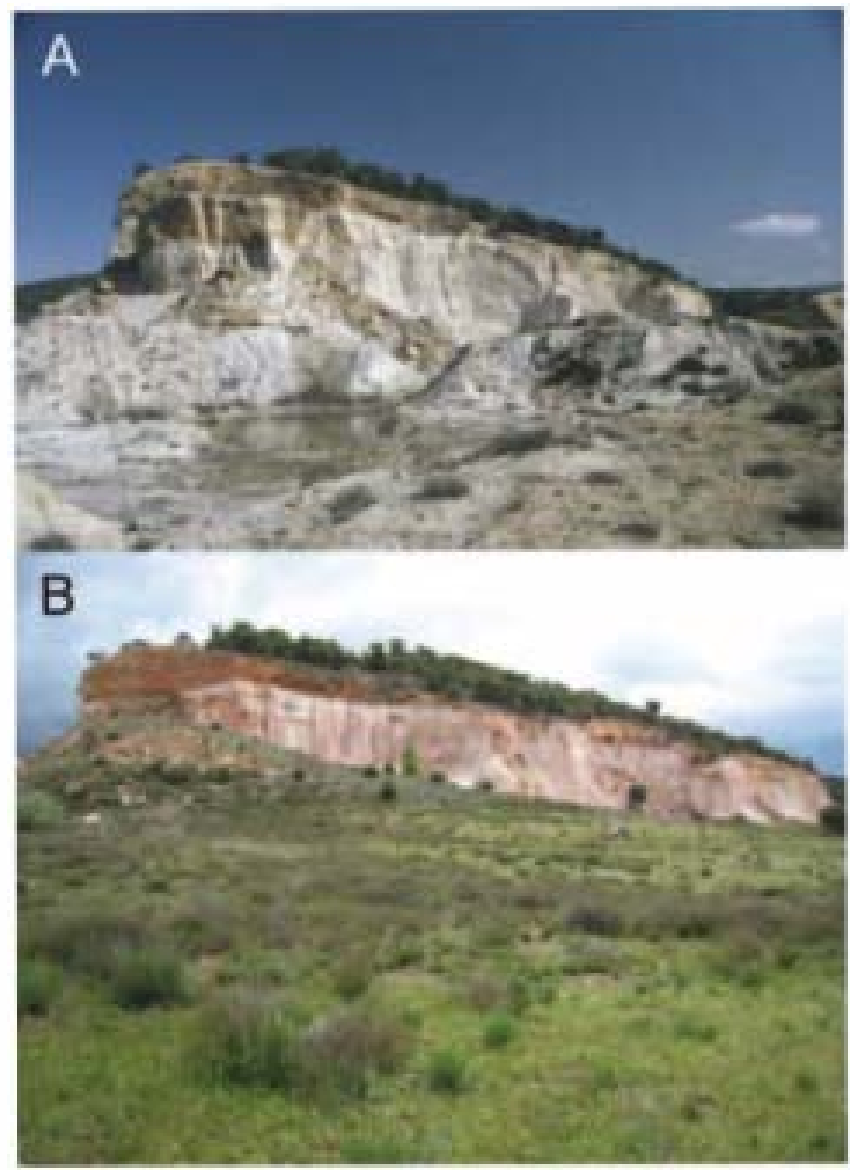

Figure 15. The recover of vegetasion and soilsat tie reconstructed concave slope and the evolution of the highwalterench sector have occurred witlout any mainten ance. (A) 1995; (B) 2007.

tion of the rainfall conditions for the same period - constitutes invaluable data for regional extrapolation, countering the difficulty and high degree of uncertainty of ebtaining that information from theoretical slope models.

We must consider, finally, that th is geomerphic reclamation slope model was designed as twe-dimensional (at a slope scaie), because of the strall size of the quarry. Therefore, it can be considered as a useful component to be included in larger $3 \mathrm{D}$ geomorph ic re:clarration $d \epsilon$ :signs of contour mining and quaried slope scenarios. Arguably, a combination of this hillslope profile model with the construction of an integrated $3 \mathrm{D}$ drainage network, breaking the reclairrved area intoseveral watersheds with strearn channels perpendiallar to the high. wall (Moasles and Bugosh, 2007), should be an eptimum model for geomorphic reclarration of centour mining and quarried slopes, because it considers drainage ranagement as well as slope evolution. A cornbination of geomorphic hillslope models with integrated geomorphic drainage management has been cornpleted at several sites in the USA since 2000 (Bugesh, 2000, 2002, 2004, 2006a). Besides, as a lesson learned at La Revilla, a specific cornb ination of the highwalltrench-concave: slope mede!l with an integrated 3D drainage network has been executed in other slepe quarry reclamations of Cental Spain since 208.

Actnostedgements-This study is an outcome of research Projecl CGL2006-07207. Andrés Díez, Alberto Díez, Javier Pedraza, Ros Carrasce and Saydmino de Alba collaborated atdiff erent stages of the reclamation and monitonng process. Jose $M$. I licolau RIniverslay of Alcalá, Spain) and Wayne Newell US Geolegical Survey, Reston, VA, USA) reviewed an eariier version of the manuscript. Mario Codfrey 


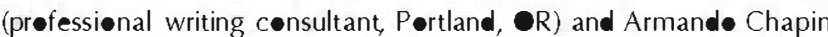
Redriguez (Freelance Technical and Scientific Editor) edited the man-

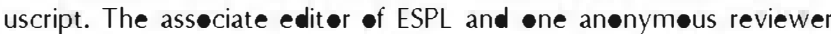

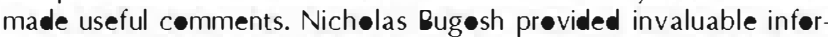

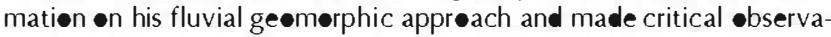
tiøns that clearly impreved the content $\bullet$ the paper.

\section{References}

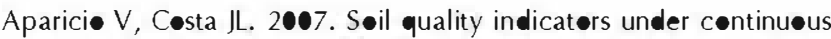
crepping systems in the Argentinean Pampas. Soil and Tillage Research 96(1-2): 557-567. DOI:10.1016/j.still.2007.05.006

Bell JC, Daniels WL, Zipper CE. 1989. The practice of 'appreximate -riginal cont•ur' in the Central Appalachians. I. Sløpe stability and eresien petential. Landscape and Urban Planning 18: 127-138. Dl: 10.1016/0169-2046(89)90004-2

Bender MJ, Sawatsky L, Løng D, Andersøn PG. 2000. A strategy før determining acceptable sediment yield for reclaimed mine lands. In Reclaimed Land: Erosion Control, Solls and Ecology, Haigh MJ (ed). Balkema: Retterdam; 37-50.

BrejdaJJ, Meerman TB, SmithJL, Karlen DL, Allan DL, Da• TH. 2000. Distribution and variability of surface søil preperies at a regienal scale. Soil Science Society of America Journal 64: 974-982.

Brenner FJ. 1985. Land reclamatien after strip ceal mining in the United States. Mining Magazine September: 211-217.

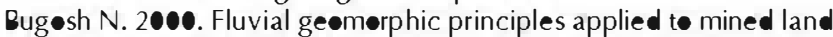
reclamation. In OSM Alternatives to Cradient Terraces Workshop, January 2000. Office of Surface Mining: Farmingten, NM.

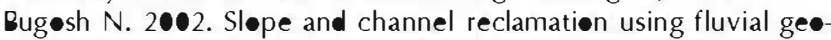
merphic principles at San Juan Coal Company Mines in New Mexice. In Approaching bond release: Postmining land use in the arid and semi-arid west, Abstracts, August 25-30, 2002, Office of Surface Mining, Nerth Dakøta State University and Nerth Dakøta Public Service Cømmissiøn: Bismarck, ND.

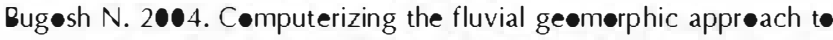
land reclamation. In 2004 National Meeting of the American Society of Mining and Reclamation and The 25th West Virginia Surface Mine Drainage Task Force, April 18-24, 2004. Barnhisel RI (ed). ASMR: Lexingten, KY; 240-258.

Bug•sh N. 2006a. Regienal variatiens in stable landferms. And høw critical elements can be used t• design reclamatien landf $\bullet$ rms. In Billings Land Reclamation Symposium, June 4-8, 2006, Billings MT. Barnhisel RI (ed). BLRS and ASMR: Lexingten, KY; 156-158.

Bugesh N. 206b. Basic Manual for Fluvial Ceomorphic Review of Land form Designs. Office of Surface Mining of the US Department -f the Interier: Denver.

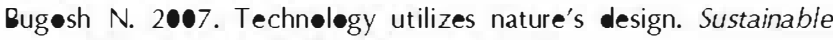
Land Development Today February: 16-17.

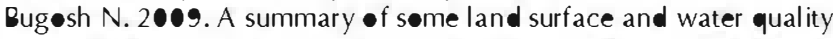

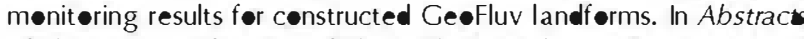
of the Joint Conference of the 26th Annual American Society of Mining and Reclamation Meeting and 11th Billings Land Reclamation Symposium, Barnhisel RI (ed). BLRS and ASMR: Lexingten, KY; 10.

Bug•sh N. Eckels R. 2006. Restering er $\bullet$ sienal features in the desert. New landf $\bullet r m$ design søftware and autemated machine guidance cømbine in award-winning reclamatiøn prøject. Coal Age 111(3): $30-32$.

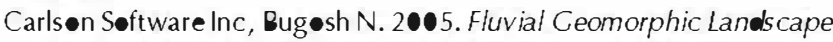
Design Computer Sofware. US Patent Office, publicatien number W/2005/036331, internatienal application number PCT/ US2004/02995.

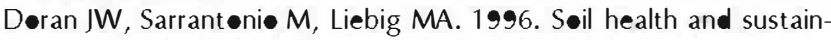
ability. Advances in Agronomy 56: 1-54. D I:10.1016/ S०065-2113(08)60178-9

Envirønment Australia. 1998. Landform Design for Rehabilitation. Department of the Envirenment: Canberra.

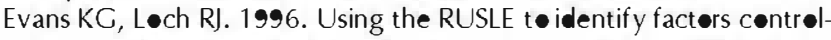
ling eresien rates of mine søils. Land Degradation and Rehabilitation 7: 267-277.

Evans KG, Sayner MJ, Willgeese R, Riley SJ. 2000. Pest-mining landform evelution modelling: 1. Derivation of sediment

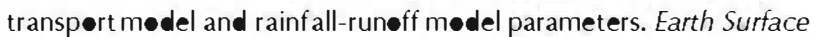
Processes and Landforms 25: 743-763. DQ1:10.1002/

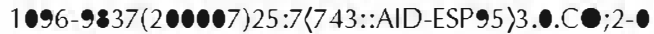

Evans MJ, Willgeøse GR. 2000. Pest-mining evelutien landferm modelling: 2. Effects of vegetation and surface ripping. Earth Surface Processes and Landforms 25: 803-823. DO1:10.1002/ 1096-9837(200008) $25: \mathbf{8}<\mathbf{8 0 3}:: A I D-E S P 96>3.0 . C) ; 2-4$

Geodman JM, Haigh MJ. 1981. Slepe evelution on abandened

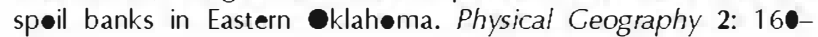
173.

Gødfrey A, Cleaves ET. 1991. Landscape analysis: theoretical censideratiens and practical needs. Environmental Geology and Water

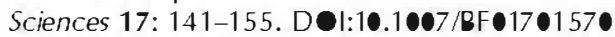

Haigh MJ. 1979. Grøund retreat and sløpe ev lutiøn $\bullet$ regraded surface-mine dumps, Waunaf $\bullet$, Gwent. Earth Surface Processes 4: 183-189. DOI: $10.1002 /$ esp. 3290040208

Haigh MJ. 1980. Sløpe retreat and gullying $\bullet$ revegetated surface mine dumps, Waun Hescyn, Gwent. Earth Surface Processes 5(1): 77-79. D I: $10.1002 /$ esp. 3760050108

Haigh MJ 1985. The experimental examination of hill-slepe evelutien and the reclamation of land disturbed by coal mining. In Ceography Applied to Practical Problems, Jehnsen JH (ed). Gee Beøks: Nerwich; 123-138.

Haigh MJ. 1992. Pr $\bullet b l e m s$ in the reclamation $\bullet$ c cal-mine disturbed lands in Wales. International Journal of Surface Mining and Reclamation 6(1): 31-37. DOl:10.1080/09208119208944313

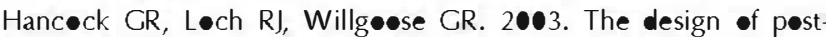
mining landscapes using geømørphic principles. Earth Surface Processes and Land forms 28: 1097-1110. DO1:10.1002/esp.518

Heøke RL. 1994. On the efficacy of humans as geømerphic agents. CSA Today 4: 217-225.

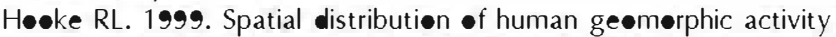
in the United States: cømparisøn with rivers. Earth Surface Processes and Landforms 24: 687-692. D 1:10.1002/(SICl)1 096-9837 (199908) 24:8<687::AID-ESP991〉3.0.C ;2-\#

IUSS Wørking Grøup WRB. 2007. World Reference Base for Soil

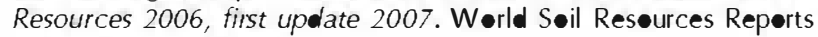
N•. 103, FA๑: Røme.

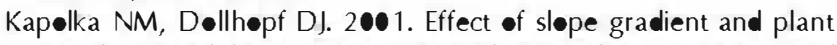
grøwth $\bullet$ s seil loss $\bullet$ recønstructed steep sløpes. International Journal of Surface Mining, Reclamation and Environment 15(2): 86-99. DOl: 10.1076/ijsm.15.2.86.3416

Keys MJ, McKenna G, Sawatsky L, V an Meer T. 1995. Natural analegs fer sustainable reclamation landscape design at Syncrude. In Proceedings of the Environmental Management for Mining Conference, Saskateen, SK, Canada, Oct. 25-27, 1995.

Larsøn WE, Pierce FJ. 1994. The dynamics $\bullet$ f $\bullet$ il quality as a measure -f sustainable management. In Defining Soil Quality for a Sustain-

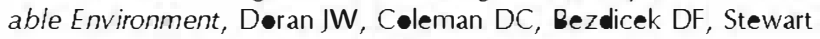

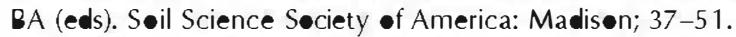

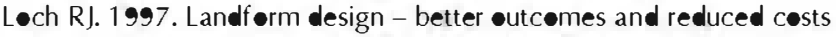

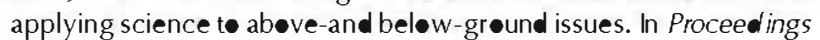
of the $22^{\text {nd }}$ Annual Environmental Workshop. Minerals Cuncil of Australia: Adelaide; 55-563.

Lucía A, Vicente F, Martin C, Martín Duque JF, Sanz MA, Andrés C,

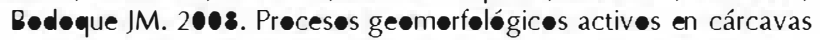
del berde del piedemente nerte de la sierra de Guadarrama (pr $\bullet$ vincial de Segevia, España). Boletín de la Real Sociedad Española de Historia Natural (Sección Ceológica) 102(1-3): 47-69.

Martín-Duque JF, Pedraza J, Díez A, Sanz MA, Carrasc• RM. 1998. A geømerph legical design for the rehabilitation $\bullet$ an abandened sand quarry in central Spain. Landscape and Urban Planning 42(1):

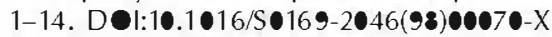

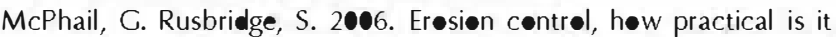
- really? In Proceedings of the 2006 Workshop of Environmental Management, Coldfields Environmental Management Group.

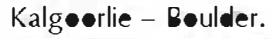

Measles D. Bugøsh N. 2007. Making and building a fluvial geømer phic reclamation design at an active dragline mine using the Geo Fluv $^{\top M}$ Design Methed. In Joint Conference of the $24^{\text {th }}$ Annual Meetings of the American Society of Mining and Reclamation, Gillette, WY, June 2-7. Barnhisel RI (ed). ASMR: Lexingten, KY; 449-456. 
MF. 1999. Máximas Huvias diarias en la España peninsular. Ministeri• de Fømente: Madrid.

Nic lau JM. 2002. Runøff generatiøn and reuting $\bullet$ artificial sløpes in a Mediterranean - continental envirenment: the Teruel cøalfield, Spain. Hydrological Processes 16: 631-647. D@1:10.1002/ hyp.308

Nic $\bullet$ lau JM. 2003. Trends in relief design and censtruction in •pencast mining reclamatien. Land Degradation and Development 14: 215-226. DOl:10.1002//dr.548

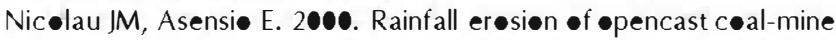
lands: ecelegical perspective. In Reclaimed Land: Erosion Control, Soils and Ecology, Haigh MJ (ed). Balkema: Rotterdam; 51-73.

-sterkamp WR, Merten RA. 1996. Envirenmental impacts •f urbanizatien and mining: an internatiønal prøject $\bullet n$ gløbal change: CSA Today 6(7): 14-15.

-sterkamp WR, Jeseph WL. 2000. Climatic and hydrelegic facters asseciated with reclamation. In Reclamation of Drastically isturbed Lands, Barnishel R, Darmedy R, Daniels W (eds). American

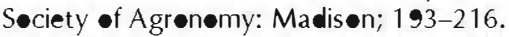

Riley SJ. 1995. Geemerphic estimates $\bullet$ the stability $\bullet$ a uranium mill tailings cøntainment cever, Nabarlek, NT, Australia. Land Degradation and Rehabilitation 6: 1-16. DOI: $10.1002 /$ Idr.34000601 2

Sánchez CE, Wøed MK. 1989. Infiltratiøn rates and er $\bullet$ siøn assøciated with reclaimed ceal mine speils in West Central New Mexice. Landscape and Urban Planning 17: 151-168. DOl:10.1016/ 0169-2046(89)90023-6

Sanz MA, Martín-Duque JF, Martín C, Lucía A, Nicelau JM, Pedraza J, Sánchez L, Ruiz R, García A. 2008. Silica sand slepe gullying and mining in Central Spain: erøsien precesses and geømerphic reclamation of conteur mining. In Geo-Environment and Landscape Evolution I/I, Mander U, Brebbia CA, Martín Duque JF (eds). WIT Press: Søuthampten; 3-14.

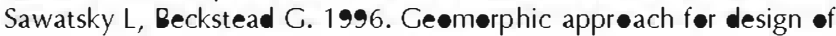
sustainable drainage systems for mineland reclamation. International Journal of Mining, Reclamation and Environment 10(3): 127129. DOI:10.1 080/09208119608964815

Sawatsky L, Tuttle S. 1996. Occurrence and grøwth $\bullet$ gullies $\bullet$ mine disturbed lands. In $21^{\text {st }}$ Annual Meeting of the Canadian Land Reclamation Association. Calgary, Alberta.

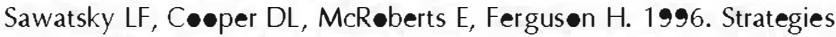
for reclamation of tailings impoundments. International Journal of Mining, Reclamation and Environment 10(3): 131-134. D०I:10.1080/09208119608964816

Sawatsky LF, Beckstead G, Løng D. 1998. Integrated mine water management planning for envir $\bullet$ nmental pretectiøn and mine prof- itability. International Journal of Surface Mining Reclamation and Environment 12(1): 37-39. D 1:10.1 080/09208119808944019

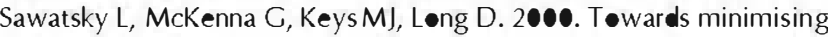
the long-term liability of reclaimed mined sites. In Reclaimed Land: Erosion Control, Soils and Ecology, Haigh MJ. (ed). Balkema: Retterdam; 21-36.

Schør HJ, Gray DH. 2007. Landforming. An environmental approach to hillside development, mine reclamation and watershed restora-

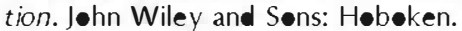

Schumm SA, Rea DK. 1995. Sediment yield frem disturbed earth systems. Ceology 23: 391-394. D@I:10.1130/0091-7613(1995) 23 $<391$ :SYFDES $>2.3$.C ; 2

Seybøld CA, Mausbach MJ, Karlen DL, Røgers HH. 1997. Quantificatien $\bullet$ søil quality. In Soil Processes and the Carbon Cycle, Lal R,

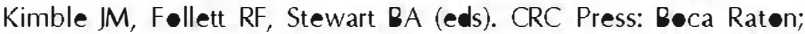
$387-404$

T•y TJ, Hadley RF. 1987. Geomorphology of Disturbed Lands. Academic Press: Lønden.

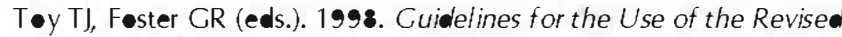
Universal Soil Loss Equation (RUSLE), version 1.06, on Mined Lands, Construction Sites, and Reclaimed Lands. Office of Surface Mining, Reclamation, and Enfercement: Denver.

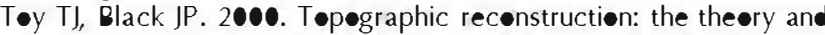
practice. In Reclamation of Dastically isturbed Lands, Barnishel

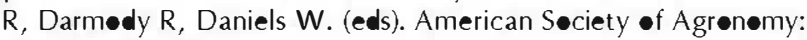
Madisen; 41-75.

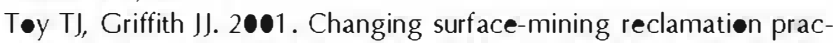
tices in Minas Gerais, Brazil. International Journal of Surface Mining, Reclamation and Environment 15(1): 33-51. DOl:10.1076/ ijsm.15.1.33.3425

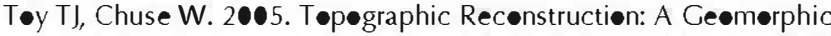
Apprøach. Ecological Engineering 24(1-2): 29-35. D@1:10.1016/j. eceleng.2004.12.014

Wilkinsøn BH, McElrøy J. 2007. The impact $\bullet$ humans $\bullet$ c c $\bullet$ tinental eresien and sedimentation. Ceological Society of America Butletin 119(1/2): 140-156. DOI:10.1130/B25899.1

Willgeøse G, Riley S. 1998. The long-term stability of engineered landferms $\bullet$ the Ranger Uranium Mine, Nerthern Territery, Australia. Application of a catchment evelutien medel. Earth Surface Processes and Landforms 23: 237-259. DQI:10.1002/

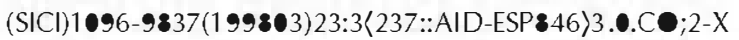

Zipper CE, Daniels WL, Bell JC. 1989. The practice of 'appr ximate

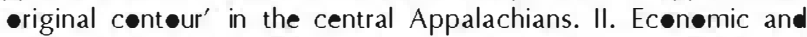
envirenmental consequences of an alternative. Landscape and Urban Planning 18: 139-152. 